\title{
Amyloid-Beta Mediates Homeostatic Synaptic Plasticity
}

\author{
Christos Galanis, ${ }^{1,2}$ Meike Fellenz, ${ }^{3}$ Denise Becker, ${ }^{3}$ Charlotte Bold, ${ }^{4}$ Stefan F. Lichtenthaler, ${ }^{5,6,7}$ \\ Ulrike C. Müller, ${ }^{4}$ Thomas Deller, ${ }^{3}$ and Andreas Vlachos ${ }^{1,8,9}$ \\ ${ }^{1}$ Department of Neuroanatomy, Institute of Anatomy and Cell Biology, Faculty of Medicine, University of Freiburg, 79104 Freiburg, Germany, \\ ${ }^{2}$ Faculty of Biology, University of Freiburg, 79104 Freiburg, Germany, ${ }^{3}$ Institute of Clinical Neuroanatomy, Dr. Senckenberg Anatomy, Neuroscience \\ Center, Goethe-University Frankfurt, 60590 Frankfurt, Germany, ${ }^{4}$ Institute of Pharmacy and Molecular Biotechnology, Functional Genomics, \\ Ruprecht-Karls University, 69120 Heidelberg, Germany, ${ }^{5}$ German Center for Neurodegenerative Diseases, 81377 Munich, Germany, \\ ${ }^{6}$ Neuroproteomics, School of Medicine, Klinikum Rechts der Isar, Technical University Munich, 81675 Munich, Germany, ${ }^{7}$ Munich Cluster for \\ Systems Neurology, 81377 Munich, Germany, ${ }^{8}$ Center Brain Links Brain Tools, University of Freiburg, 79110 Freiburg, Germany, and ${ }^{9}$ Center for \\ Basics in Neuromodulation, Faculty of Medicine, University of Freiburg, 79106 Freiburg, Germany
}

The physiological role of the amyloid-precursor protein (APP) is insufficiently understood. Recent work has implicated APP in the regulation of synaptic plasticity. Substantial evidence exists for a role of APP and its secreted ectodomain APPs $\alpha$ in Hebbian plasticity. Here, we addressed the relevance of APP in homeostatic synaptic plasticity using organotypic tissue cultures prepared from $A P P^{-/-}$mice of both sexes. In the absence of APP, dentate granule cells failed to strengthen their excitatory synapses homeostatically. Homeostatic plasticity is rescued by amyloid- $\beta$ and not by APPs $\alpha$, and it is neither observed in $A P P^{+/+}$tissue treated with $\beta$ - or $\gamma$-secretase inhibitors nor in synaptopodin-deficient cultures lacking the $\mathrm{Ca}^{2+}$-dependent molecular machinery of the spine apparatus. Together, these results suggest a role of APP processing via the amyloidogenic pathway in homeostatic synaptic plasticity, representing a function of relevance for brain physiology as well as for brain states associated with increased amyloid- $\beta$ levels.

Key words: Alzheimer's disease; amyloid-beta; APP processing; homeostatic plasticity; sAPPalpha; secretases

Significance Statement

Considerable effort has been directed to better understand the pathogenic role of the amyloid precursor protein (APP) and its cleavage products in neurodegeneration, with a major focus on the accumulation and deposition of "synaptotoxic" amyloid$\beta(\mathrm{A} \beta)$ peptides, which are produced by sequential cleavage of APP by $\beta$ - and $\gamma$-secretases. Although the amyloidogenic APP processing pathway has recently been targeted in patients with Alzheimer's disease, the physiological role of APP/A $\beta$ remains unclear, which limits our understanding of how such interventions could influence brain functions in health and disease. Here, we report an essential role of $\mathrm{A} \beta$ (and not APPs $\alpha$ ) in homeostatic synaptic plasticity, suggesting that this could be a major physiological function of $\mathrm{A} \beta$ in the healthy brain.

Received July 15, 2020; revised Mar. 2, 2021; accepted Mar. 28, 2021.

Author contributions: C.G., U.C.M., T.D., and A.V. designed research; C.G., M.F., D.B., S.F.L., and A.V. performed research; C.G., M.F., and S.F.L. analyzed data; C.G., S.F.L., U.C.M., T.D., and A.V. edited the paper; C.G. and A.V. wrote the paper; C.B. and U.C.M. contributed unpublished reagents/analytic tools; A.V. wrote the first draft of the paper.

This work was supported by the Federal Ministry of Education and Research, Germany (BMBF OGEAM) to T.D and U.C.M., under Germany's Excellence Strategy within the framework of the Munich Cluster for Systems Neurology (EXC 2145 SyNergy ID 390857198) to S.F.L., and Deutsche Forschungsgemeinschaft MU1457/14-1 to U.C.M., FOR 1332 to U.C.M., T.D., and A.V., CRC1080 to T.D. and A.V., and CRC/TRR 167 to A.V. We thank Anke Biczysko, Sussana Glaser, Katrin Moschke, and Sigrun Nestel for excellent technical assistance; and Drs. Christian Buchholz and Tobias Abel for providing AAV vectors.

D. Becker's present address: Department of Neurology, University Hospital of Zurich, Zurich, Switzerland. The authors declare no competing financial interests.

Correspondence should be addressed to Andreas Vlachos at andreas.vlachos@anat.uni-freiburg.de. https://doi.org/10.1523/JNEUROSCI.1820-20.2021

Copyright $\odot 2021$ Galanis et al.

This is an open-access article distributed under the terms of the Creative Commons Attribution 4.0 International license, which permits unrestricted use, distribution and reproduction in any medium provided that the original work is properly attributed.

\section{Introduction}

In recent years, considerable effort has been directed to better understand the pathogenic role of the amyloid precursor protein (APP) and its cleavage products in neurodegeneration (Bohm et al., 2015). It has been proposed that the accumulation and deposition of "synaptotoxic" amyloid- $\beta$ (A $\beta)$ peptides, which are produced by sequential cleavage of APP by $\beta$ - and $\gamma$-secretases (Lichtenthaler et al., 2011), are responsible for synapse loss, which is regarded as the significant structural hallmark of cognitive decline in Alzheimer's disease (AD). In comparison, the physiological functions of cleavage products generated along the "amyloidogenic pathway," which are also produced in low concentrations in the healthy brain (Seubert et al., 1992; Shoji et al., 1992; Cirrito et al., 2003), are incompletely understood (Kamenetz et al., 2003; Abramov et al., 2009; Puzzo et al., 2011).

Studies using mouse mutants lacking APP or APP-gene family members (Zheng et al., 1995; von Koch et al., 1997; Magara et 
al., 1999; Herms et al., 2004; Ring et al., 2007) have shed new light on the role of APP in neuronal migration, synaptogenesis, and synaptic structure and function (Müller et al., 2017). Specifically, alterations in dendritic arborization and spine densities have been reported in pyramidal cells of $A P P^{-1-}$ mice, and these changes are accompanied by defects in the ability of neurons to express long-term potentiation (LTP) of excitatory synaptic strength and alterations in spatial learning (see, e.g., Muller et al., 1994; Zheng et al., 1995; Li et al., 1996; Dawson et al., 1999; Ring et al., 2007; Tyan et al., 2012; for review, see Ludewig and Korte, 2016; Müller et al., 2017). Several of the reported phenotypes of $A P P^{-1-}$ mice are rescued by the APP secreted ectodomain $\alpha$ (APPs $\alpha$ ) (e.g., Weyer et al., 2014; Hick et al., 2015; Richter et al., 2018; Tan et al., 2018). Therefore, it has been proposed that APP could play an important role in neuronal structural and functional plasticity under physiological conditions through the "non-amyloidogenic pathway," which produces APPs $\alpha$. The physiological function of $\mathrm{A} \beta$ has, however, remained enigmatic.

In an attempt to learn more about the role of APP and its cleavage products in synaptic plasticity, we here tested for its significance in another major plasticity mechanism (i.e., homeostatic synaptic plasticity). The ability of neurons to adjust their synaptic strength in a compensatory manner is considered to be fundamental for physiological brain function (Turrigiano, 1999; Styr and Slutsky, 2018). It is also a relevant compensatory mechanism in the context of brain diseases and a promising therapeutic target (Andre et al., 2018; Smith-Dijak et al., 2019). In contrast to Hebbian synaptic plasticity (e.g., LTP), homeostatic plasticity is based on negative feedback mechanisms (Turrigiano, 2008; Lisman, 2017). Meanwhile, several molecular players have been identified that control homeostatic synaptic plasticity (Stellwagen and Malenka, 2006; Goddard et al., 2007; Cingolani et al., 2008; Sun and Turrigiano, 2011; Walters and Josselyn, 2019). Recently, a potential role of APP in homeostatic synaptic plasticity has been discussed (Hoe et al., 2012; Jang and Chung, 2016; Andre et al., 2018; Styr and Slutsky, 2018). However, the mechanistic link between APP and homeostatic plasticity remains unclear because homeostatic plasticity could be induced by APP and its cleavage products or indirectly by synapse loss and cell death (i.e., denervation/deprivation-induced homeostatic adaptation) (see, e.g., Vlachos et al., 2013; Gilbert et al., 2016; Barnes et al., 2017). Here, we studied the role of APP in non-diseased brain tissue and report an essential role of $\mathrm{A} \beta$ in homeostatic plasticity of excitatory neurotransmission, suggesting that this could be one of the major physiological functions of $\mathrm{APP} / \mathrm{A} \beta$ in the normal brain.

\section{Materials and Methods}

Ethics statement. Mice were maintained in a $12 \mathrm{~h}$ light/dark cycle with food and water available ad libitum. Every effort was made to minimize the distress and pain of animals. All experimental procedures were performed according to German animal welfare legislation and approved by the appropriate animal welfare committee and the animal welfare officer of Freiburg University.

Animals. WT C57BL/6J, SYNPO ${ }^{-1-}$ (Deller et al., 2003), $A P P^{-1-}(\mathrm{Li}$ et al., 1996), $A P P s \alpha-K I$ mice (Ring et al., 2007), and their WT littermates were used in this study.

Preparation of tissue cultures. Entorhino-hippocampal tissue cultures were prepared at postnatal day 4-5 from mice of either sex as previously described (Vlachos et al., 2012). The incubation medium consisted of $50 \%(\mathrm{v} / \mathrm{v})$ MEM, 25\% (v/v) basal medium eagle (BME), 25\% (v/v) heat-inactivated normal horse serum, $25 \mathrm{~mm}$ HEPES, 0.15\% (w/v) $\mathrm{NaHCO}_{3}, 0.65 \%$ (w/v) glucose, $0.1 \mathrm{mg} / \mathrm{ml}$ streptomycin, $100 \mathrm{U} / \mathrm{ml}$ penicillin, and $2 \mathrm{~mm}$ Glutamax. The $\mathrm{pH}$ was adjusted to 7.3, and the medium was changed 3 times per week. Tissue cultures were allowed to mature in vitro for at least $18 \mathrm{~d}$ before any experimental procedure.

Whole-cell patch-clamp. Whole-cell patch-clamp recordings of dentate gyrus granule cells were conducted at $35^{\circ} \mathrm{C}$. The bath solution contained $126 \mathrm{~mm} \mathrm{NaCl}, 2.5 \mathrm{~mm} \mathrm{KCl}, 26 \mathrm{~mm} \mathrm{NaHCO}, 1.25 \mathrm{~mm} \mathrm{NaH}_{2} \mathrm{PO}_{4}$, $2 \mathrm{mM} \mathrm{CaCl}_{2}, 2 \mathrm{~mm} \mathrm{MgCl}_{2}$, and $10 \mathrm{~mm}$ glucose and was saturated with 95\% $\mathrm{O}_{2} / 5 \% \mathrm{CO}_{2}$. For miniature and spontaneous AMPAR-mediated excitatory postsynaptic current (mEPSC/sEPSC) recordings as well as current-clamp (input-output) recordings, patch pipettes contained 126 $\mathrm{mm}$ K-gluconate, $4 \mathrm{~mm} \mathrm{KCl}, 4 \mathrm{~mm}$ ATP-Mg, $0.3 \mathrm{~mm} \mathrm{GTP}-\mathrm{Na}_{2}, 10 \mathrm{~mm}$ PO-creatine, $10 \mathrm{~mm}$ HEPES, and $0.1 \%$ (w/v) biocytin (pH 7.25 with $\mathrm{KOH}, 290$ mOsm with sucrose). For NMDAR-mediated mEPSC recordings, patch pipettes contained $120 \mathrm{~mm} \mathrm{CsCH}_{3} \mathrm{SO}_{3}, 8 \mathrm{~mm} \mathrm{CsCl,} 1 \mathrm{~mm}$ $\mathrm{MgCl}_{2}, 0.4$ mm EGTA, 2 mм ATP-Mg, 0.3 mm GTP-Na 2,10 mм PO-creatine, $10 \mathrm{~mm}$ HEPES, and $5 \mathrm{~mm}$ QX-314 (pH 7.25 with $\mathrm{CsOH}, 295$ mOsm with sucrose). For miniature and spontaneous inhibitory postsynaptic current (mIPSC/sIPSC) recordings, patch pipettes contained 40 $\mathrm{mm} \mathrm{CsCl}, 90 \mathrm{~mm}$ K-gluconate, $1.8 \mathrm{~mm} \mathrm{NaCl}, 1.7 \mathrm{~mm} \mathrm{MgCl}$, $3.5 \mathrm{~mm} \mathrm{KCl}$, 0.05 mM EGTA, 2 mM ATP-Mg, 0.4 mm GTP- $\mathrm{Na}_{2}, 10 \mathrm{~mm}$ PO-creatine, $10 \mathrm{~mm}$ HEPES (pH 7.25, with $\mathrm{CsOH}, 270 \mathrm{mOsm}$ with sucrose). AMPAR-mediated mEPSCs were recorded in the presence of $10 \mu \mathrm{M} D$ APV and $0.5 \mu \mathrm{M}$ TTX, NMDAR-mediated mEPSCs in the presence of $10 \mu \mathrm{M}$ CNQX and $0.5 \mu \mathrm{M}$ TTX, and mIPSCs in the presence of $0.5 \mu \mathrm{M}$ TTX, $10 \mu \mathrm{M}$ D-APV, and $10 \mu \mathrm{M}$ CNQX. sEPSCs were recorded without the addition of any drugs in the bath solution and sIPSCs in the presence of $10 \mu \mathrm{m} \mathrm{D}$-APV and $10 \mu \mathrm{m}$ CNQX. Current-clamp recordings were performed in the presence of $10 \mu \mathrm{M} \mathrm{D}-\mathrm{APV}, 10 \mu \mathrm{M} \mathrm{CNQX}$, and $10 \mu \mathrm{M}$ bicuculline methiodide. Neurons were recorded at a holding potential of $-70 \mathrm{mV}$ for mIPSCs/sIPSCs and AMPAR-mediated mEPSCs/sEPSCs. NMDAR-mediated mEPSCs were acquired at $+40 \mathrm{mV}$. For currentclamp recordings, neurons were hyperpolarized with $-100 \mathrm{pA}$ and then depolarized up to $+200 \mathrm{pA}$ with 1 -s-long $10 \mathrm{pA}$ current injection steps. Series resistance was monitored in 2 min intervals and recordings were discarded if the series resistance reached $\geq 30 \mathrm{M} \Omega$ and the leak current changed significantly.

Reconstruction of dendritic trees and spine density analysis. Dentate granule cells were patched with Alexa-568 $(10 \mu \mathrm{M})$ added to the internal solution and filled for $10 \mathrm{~min}$ in whole-cell configuration for visualization of identified cells. Confocal image stacks of granule cells $(512 \times 512$ pixel, voxel size $0.49 \times 0.49 \times 2 \mu \mathrm{m}$ ) were acquired directly at the electrophysiology setup using a Zeiss LSM Exciter confocal microscope with a $40 \times$ water immersion objective lens (0.8 NA; Carl Zeiss). Granule cells were manually reconstructed in $3 \mathrm{D}$ and analyzed using Neurolucida/ NeuroExplorer software (MBF Bioscience). Total dendritic length (TDL) was calculated as the sum of length of all reconstructed dendritic segments of a given cell. For Sholl analysis, concentric spheres with diameters increasing in $20 \mu \mathrm{m}$ increments were drawn around the cell soma, and the number of dendrites intersecting each sphere was calculated.

Immunostaining and imaging. Tissue cultures were fixed in a solution of $4 \%(\mathrm{w} / \mathrm{v})$ paraformaldehyde (PFA) and $4 \%(\mathrm{w} / \mathrm{v})$ sucrose in 0.01 M PBS for $1 \mathrm{~h}$, followed by $2 \%(\mathrm{w} / \mathrm{v})$ PFA and $30 \%(\mathrm{w} / \mathrm{v})$ sucrose in 0.01 м PBS overnight. For synaptopodin (Synpo) staining, $30 \mu \mathrm{m}$ cryosections were prepared and stained with antibodies against synaptopodin (1:1000; SE-19 Sigma Millipore, RRID:AB_261570). Sections were incubated for $1 \mathrm{~h}$ with $10 \%(\mathrm{v} / \mathrm{v})$ normal goat serum (NGS) in $0.5 \%(\mathrm{v} / \mathrm{v})$ Triton X-100-containing PBS to reduce unspecific antibody binding and incubated for $24 \mathrm{~h}$ at $4^{\circ} \mathrm{C}$ with the primary antibody in PBS with $10 \%$ NGS and $0.1 \%$ Triton X-100. Sections were washed and incubated for 4 $\mathrm{h}$ with appropriate Alexa-labeled secondary antibodies (Invitrogen; $1: 1000$, in PBS with $10 \%$ NGS, $0.1 \%$ Triton X-100). DAPI nuclear stain was used to visualize cytoarchitecture (1:5000; in $0.01 \mathrm{M}$ PBS for $15 \mathrm{~min}$ ). Sections were washed with $0.01 \mathrm{~m}$ PBS, transferred onto glass slides, and mounted for visualization with anti-fading mounting medium. Confocal images were acquired using a Leica Microsystems TCS SP8 laser scanning microscope with $20 \times$ (NA 0.75), 40× (NA 1.30), and $63 \times(\mathrm{NA}$ 1.40) oil-submersion objectives.

Post hoc identification of recorded neurons. Tissue cultures were fixed in a solution of $4 \%(\mathrm{w} / \mathrm{v})$ PFA and $4 \%(\mathrm{w} / \mathrm{v})$ sucrose in $0.01 \mathrm{M}$ PBS 
A
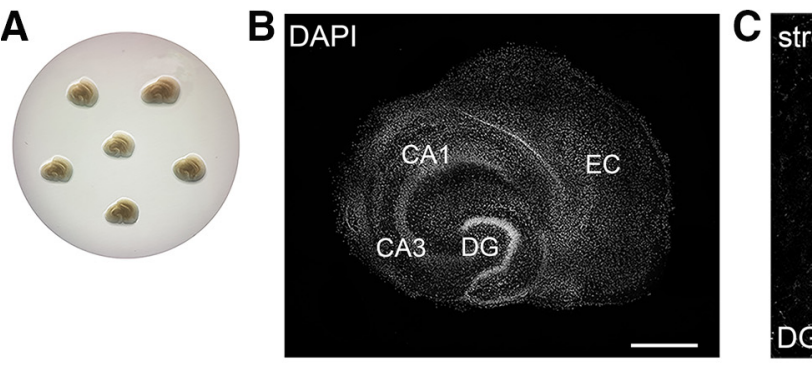

D

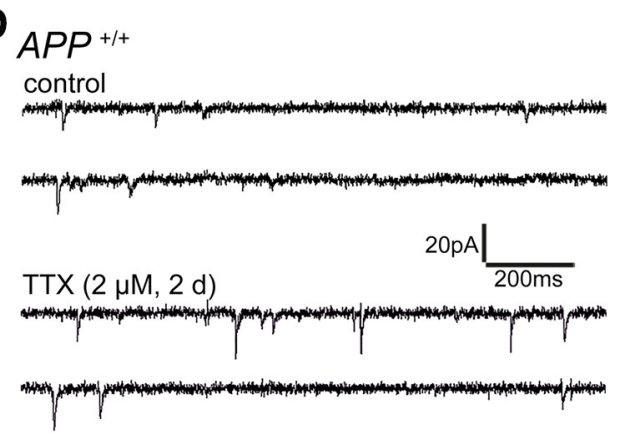

E

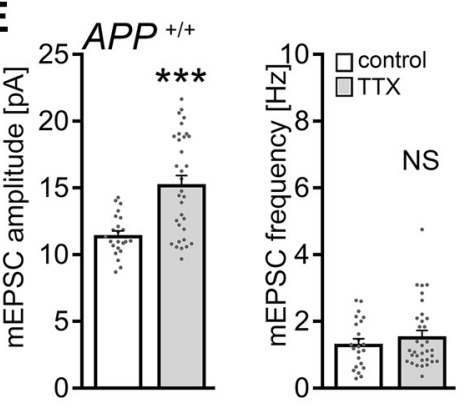

$\mathbf{F}$

$A P P^{-1}$

control

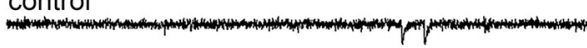

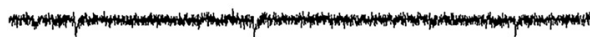
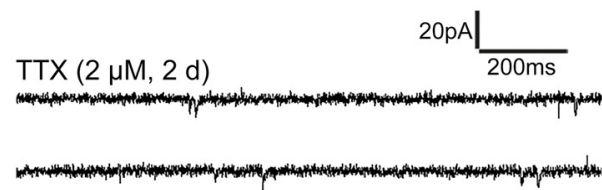

G

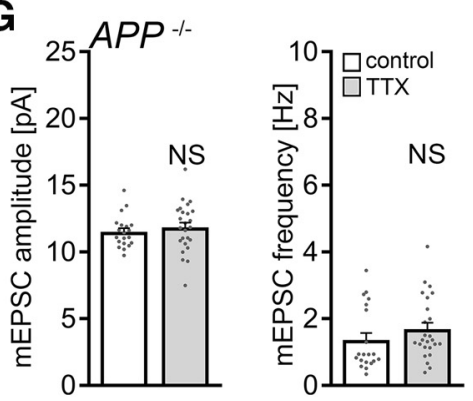

H
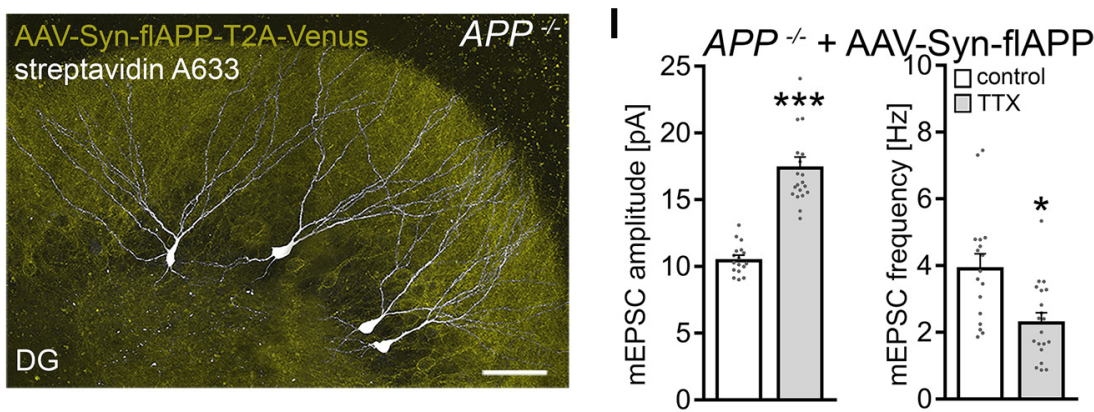

Figure 1. Dentate granule cells of APP-deficient entorhinal-hippocampal tissue cultures do not express homeostatic synaptic plasticity. $\boldsymbol{A}, \boldsymbol{B}$, Example of 3-week-old entorhinal-hippocampal tissue cultures on a membrane insert and overview at higher magnification of a representative culture. DAPI nuclear staining was used for visualization of cytoarchitecture. DG, Dentate gyrus; EC, entorhinal cortex; CA1 and CA3, cornu ammonis areas 1 and 3. Scale bar, $500 \mu \mathrm{m}$. C, Patched dentate granule cell filled with biocytin and identified post hoc with streptavidin A488. Scale bar, $25 \mu \mathrm{m}$. $\boldsymbol{D}, \boldsymbol{E}$, Sample traces and group data of AMPAR-mediated $\mathrm{mEPSC}$ recorded from granule cells in vehicle-treated (control) and TTX-treated APP ${ }^{+/+}$cultures (control, $n=23$ cells from 6 cultures; TTX, $n=33$ cells from 8 cultures; Mann-Whitney test). $\boldsymbol{F}, \mathbf{G}$, Sample traces and group data of AMPAR-mediated $\mathrm{mEPSC}$ recorded from APP-deficient $\left(A P P^{-1-}\right.$ ) dentate granule cells (control, $n=20$ cells from 6 cultures; TTX, $n=25$ cells from 7 cultures; Mann-Whitney test). $\boldsymbol{H}$, Example of post hoc identified recorded dentate granule cells (streptavidin 633, white) in an $A P P^{-1-}$ tissue culture transduced with AAV vectors expressing full-length APP (AAV-Syn-fIAPP-T2A-Venus; yellow). Scale bar, $50 \mu \mathrm{m} . I$, Expression of the fIAPP rescues the ability of dentate granule cells in APP ${ }^{-1-}$ tissue cultures to express TTX-induced homeostatic synaptic plasticity (control, $n=17$ cells from 6 cultures; TTX, $n=20$ cells from 7 cultures; Mann-Whitney test). For mEPSC amplitude, one data point is outside the axis limits in the TTX group. Individual data points are indicated in this and the following figures by gray dots. Data are mean \pm SEM. NS, Not significant. ${ }^{*} p<0.05$. ${ }^{* * *} p<0.001$.

for $1 \mathrm{~h}$. The fixed tissue was incubated for $1 \mathrm{~h}$ with $10 \%(\mathrm{v} / \mathrm{v})$ NGS and $0.5 \%(\mathrm{v} / \mathrm{v})$ Triton X-100 in $0.01 \mathrm{M}$ PBS. Biocytin (Sigma Millipore, cata$\log$ \#B4261) filled cells were stained with Alexa-488-, Alexa-568-, or Alexa-633-conjugated streptavidin (Thermo Fisher Scientific; 1:1000; in
$0.01 \mathrm{M}$ PBS with $10 \%$ NGS and $0.1 \%$ Triton $\mathrm{X}-100$ ) for $4 \mathrm{~h}$, and DAPI (Thermo Fisher Scientific) staining was used to visualize cytoarchitecture (1:5000; in $0.01 \mathrm{M}$ PBS for $15 \mathrm{~min})$. Slices were washed, transferred, and mounted onto glass slides for visualization. Transfected and streptavidin-stained granule cells were visualized with a Leica Microsystems TCS SP8 laser scanning microscope with $20 \times($ NA 0.75$), 40 \times($ NA $1.30)$, and $63 \times(\mathrm{NA} 1.40)$ oil-submersion objectives. Outer molecular layer segments were imaged with higher scan zoom, and spine densities were determined as described previously (Hick et al., 2015).

Electron microscopy. $A P P^{+/+}$and $A P P^{-/-}$ tissue cultures were fixed in $4 \%(\mathrm{w} / \mathrm{v}) \mathrm{PFA}$ and $2 \%(\mathrm{w} / \mathrm{v})$ glutaraldehyde in $0.1 \mathrm{M} \mathrm{PB}$ overnight and washed for $1 \mathrm{~h}$ in $0.1 \mathrm{M} \mathrm{PB}$. After fixation, tissue cultures were sliced with a vibratome, and the $50 \mu \mathrm{m}$ slices were incubated with $1 \%(\mathrm{w} / \mathrm{v})$ osmium tetroxide for $20 \mathrm{~min}$ in $5 \%(\mathrm{w} / \mathrm{v})$ sucrose containing $0.1 \mathrm{M} \mathrm{PB}$. The slices were washed 5 times for $10 \mathrm{~min}$ in $0.1 \mathrm{M} \mathrm{PB}$ and washed in graded ethanol [ $10 \mathrm{~min}$ in $10 \%(\mathrm{v} / \mathrm{v})$ and $10 \mathrm{~min}$ in $20(\mathrm{v} / \mathrm{v})]$. The slices were then incubated with uranyl acetate $[1 \%(\mathrm{w} / \mathrm{v})$ in $70 \%(\mathrm{v} / \mathrm{v})$ ethanol)] overnight and were subsequently dehydrated in graded ethanol $80 \%(\mathrm{v} / \mathrm{v}), 90 \%(\mathrm{v} / \mathrm{v})$, and $98 \%(\mathrm{v} / \mathrm{v})$ for $10 \mathrm{~min}$. Finally, slices were incubated with $100 \%(\mathrm{v} / \mathrm{v})$ ethanol 2 times for $15 \mathrm{~min}$ followed by two $15 \mathrm{~min}$ washes with propylene oxide. The slices were then transferred for $30 \mathrm{~min}$ in a 1:1 mixture of propylene oxide with durcupan and then for $1 \mathrm{~h}$ in durcupan. The durcupan was exchanged with fresh durcupan, and the slices were transferred in $4^{\circ} \mathrm{C}$ overnight. The slices were then embedded between liquid releasecoated slides and coverslips. Cultures were re-embedded in blocks, and ultrathin sections were collected on copper grids (compare Radic et al., 2017; Lenz et al., 2021). Electron microscopy was performed at a LEO 906E microscope (Carl Zeiss) at $4646 \times$ magnification. Acquired images were saved as TIF files and analyzed using the ImageSP Viewer software (http://sysprog.com). For each tissue culture, 10 images in the outer molecular layer of the dentate gyrus were analyzed. Dendritic spines were identified, and the sizes of postsynaptic densities (PSDs) and dense plates of spine apparatuses were assessed with the line tool.

Pharmacology. Tissue cultures were treated with TTX (2 $\mu \mathrm{m}$; BioTrend, catalog \#BN0518), D-APV (50 $\mu \mathrm{M}$; Tocris, catalog \#0106), synthetic A $\beta_{1-42}(1.5 \mu \mathrm{M}$; Bachem, catalog \#4014447) or $\mathrm{A} \beta_{42-1}(1.5 \mu \mathrm{M}$; Bachem, catalog \#H-3976) (Novotny et al., 2016), synthetic A $\beta_{1-40}(1.5 \mu \mathrm{M}$; Bachem, catalog \#4035886) recombinant APPs $\alpha$ (10 nM) (Hick et al., 2015); $\beta$-site APP cleaving enzyme (BACE) inhibitor C3 (20 $\mu \mathrm{M}$; Calbiochem, Sigma Millipore, catalog \#565788), Begacestat (1 $\mu \mathrm{M}$; Tocris, catalog \#4283), KN-92 (5 $\mu \mathrm{M}$; Tocris, catalog \#4130), KN-93 (5 $\mu \mathrm{M}$; Tocris, catalog \#1278), BNT77 (1.3 $\mu \mathrm{g} / \mathrm{ml}$; Wako, 
catalog \#014-26881, RRID:AB_2827702), JRD32 $(1.3 \mu \mathrm{g} / \mathrm{ml}$; RRID:AB_2827703) (Hick et al., $2015)$ for $2 \mathrm{~d}$. For the $\mathrm{A} \beta$ treatment, 0.01 м PBS was added to the lyophilized $A \beta$ peptides, followed by $3 \times 1 \mathrm{~min}$ vortexing on wet ice, and stocks were kept at $-80^{\circ} \mathrm{C}$. Before treating the tissue cultures, $\mathrm{A} \beta_{1-40}, \mathrm{~A} \beta_{1-42}$, and $\mathrm{A} \beta_{42-1}$ were slowly thawed on ice and vortexed again before adding to the medium.

Viral transduction. Tissue cultures were transfected between 3 and 4 days in vitro (DIV) by adding $1 \mu \mathrm{l}$ of AAV-Syn/Venus, AAV-Syn/Venus_T2A_ APPs $\alpha$ (AAV-APPs $\alpha$ ) or $1 \mu$ l of AAV-Syn/ APP695_T2A_Venus (AAV-flAPP-Venus; kindly provided by Drs. Christian Buchholz and Tobias Abel) directly on top of each culture. Tissue cultures were then left to mature at least until 18 DIV before experimental assessment.

ELISA assay and $A \beta$ peptide quantification. Incubation medium from vehicle-only (control) and pharmacologically treated 3-week-old tissue cultures was collected, frozen immediately with dry ice, and stored at $-80^{\circ} \mathrm{C}$ (vehicle, $n=6$ wells with 36 tissue cultures; BACE inhibitor $\mathrm{C} 3, n=3$ wells with 18 tissue cultures; Begacestat, $n=3$ wells with 18 tissue cultures). For the detection of $\mathrm{A} \beta$, a VPLEX A $\beta$ Peptide Panel 1 Kit (MesoScale Discovery, catalog \#K15199E, RRID:AB_2827747) was used with a ruthenylated anti-A $\beta$ antibody (4G8 clone). The A $\beta$ peptide concentration was determined using the MSD Discovery Workbench software (MesoScale Discovery).

Conditioned concentrated incubation medium. Incubation medium from two wells in which $A P P^{+/+}$tissue cultures were cultivated was collected and concentrated in an Amicon Ultra-2 Centrifugal Filter Unit with a cut off molecular weight of $10 \mathrm{kDa}$ (Millipore, catalog \#UFC201024). Media were centrifuged for $20 \mathrm{~min}$ at $4000 \times \mathrm{g}$ at room temperature. The permeate (containing proteins $<10 \mathrm{kDa}$ ) was collected, and the retentate (with concentrated proteins $\geq 10 \mathrm{kDa}$ ) was recovered from the column by a second centrifugation at $1000 \times g$ for $2 \mathrm{~min}$. The permeate and the retentate were added to mature ( $\geq 18 \mathrm{DIV}$ ) $A P P^{-/-}$tissue cultures. $A P P^{-/-}$preparations were cultivated in a mix of $50 \%$ permeate and $50 \%$ standard incubation medium since the permeate was free of large serum proteins. The concentrated retentate (final volume 80-90 $\mu$ l) was used with $900 \mu \mathrm{l}$ of the standard incubation medium.

Experimental design and statistical analysis. Analyses were performed with the person analyzing the data blind to the experimental condition. One or two tissue cultures were used from each animal (numbers of tissue cultures used per experimental group is denoted in the figure legends). Electrophysiological data were analyzed using pClamp 10.7 software suite (Molecular Devices), MiniAnalysis (Synaptosoft), and Igor Pro 7 (Wavemetrics). Up to 300 events were analyzed per recorded neuron. Sizes of immunolabeled synaptopodin clusters were assessed using the FIJI ImageJ software package (available from https://imagej.net/ImageJ) as described previously (Vlachos et al., 2013). Numbers and sizes of spine apparatus and PSDs were calculated using the ImageSP Viewer software (http://sys-prog.com). Statistical comparisons were made using Mann-Whitney test (to compare two groups), Wilcoxon test (to compare recordings made from the same cells before and after treatment), Kruskal-Wallis test followed by Dunn's post hoc test for multiple group testing or one or two-way ANOVA as indicated in the figure captions and text (GraphPad Prism 7, GraphPad Software). $p$ values of $<0.05$ were considered a significant difference. All values represent mean \pm SEM.

Digital illustrations. Confocal image stacks were exported as 2D projections and stored as TIF files. Figures were prepared using Photoshop graphics software (Adobe). Image brightness and contrast were adjusted.
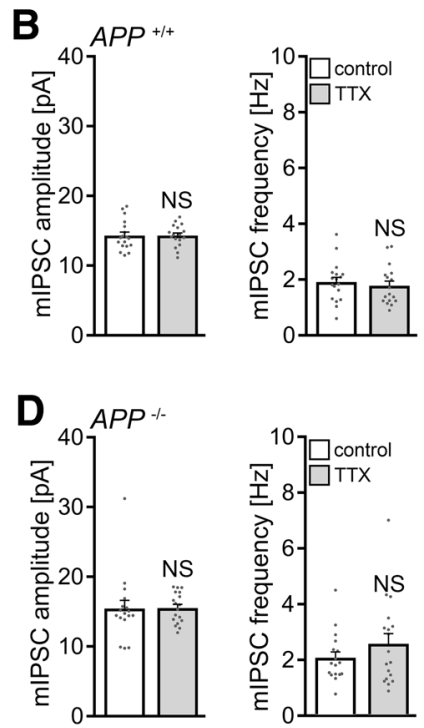

Figure 2. Dentate granule cells of WT and of APP-deficient tissue cultures do not adjust their inhibitory synapses foltreated $A P P^{-1-}$ dentate granule cells (control, $n=17$ cells from 6 cultures; $T$ TX, $n=18$ cells from 6 cultures; MannWhitney test). Data are mean \pm SEM. NS, Not significant.

\section{Results}

Homeostatic synaptic plasticity is not observed in dentate granule cells of APP-deficient entorhinal-hippocampal tissue cultures

Considering the role of the hippocampal formation and specifically the dentate gyrus in memory formation (Friedman and Goldman-Rakic, 1988; Aimone et al., 2011), 3-week-old $(\geq 18$ DIV) organotypic tissue cultures containing the entorhinal cortex and the hippocampus were prepared from $A P P^{+/+}$ and $A P P^{-1-}$ mice, including age- and time-matched $A P P^{+/+}$ littermates obtained from $A P P^{+/-}$intercrossing (Fig. 1A,B). Tissue cultures were treated with TTX $(2 \mu \mathrm{M} ; 2 \mathrm{~d})$ to block network activity, and AMPAR-mediated mEPSCs were recorded from individual dentate granule cells (Fig. 1C) to assess compensatory (i.e., homeostatic) synaptic changes.

In line with previous work (e.g., Turrigiano et al., 1998; Echegoyen et al., 2007; Kim and Tsien, 2008; Vlachos et al., 2013; Strehl et al., 2018), a homeostatic increase in excitatory synaptic strength (i.e., a robust increase in mEPSC amplitudes) was observed in the WT tissue cultures (Fig. $1 D, E$ ). In $A P P^{-1-}$ preparations, no significant changes in mEPSC properties were observed in dentate granule cells (Fig. $1 F, G$ ). Specifically, mean mEPSC amplitude was $11.5 \pm 0.3 \mathrm{pA}$ in vehicle-only-treated and $11.8 \pm 0.4 \mathrm{pA}$ TTX-treated $A P P^{-/-}$dentate granule cells $(p=0.4$; Mann-Whitney test).

In an attempt to rescue the ability of granule cells to express homeostatic synaptic plasticity, $A P P^{-/-}$tissue cultures were transfected with a bicistronic AAV vector expressing full-length murine APP (flAPP) and membrane-anchored Venus linked by a T2A site under the control of the neuronal synapsin promoter (AAV-Syn-flAPP-T2A-Venus; Fig. 1H). Cultures were transduced at 4-5 DIV and allowed to mature for at least 18 DIV before experimental assessment. A significant compensatory increase in mEPSC amplitudes from $10.5 \pm 0.3 \mathrm{pA}$ to $17.5 \pm$ 0.7 pA $(p<0.001$; Mann-Whitney test; Fig. $1 I)$ was observed in 

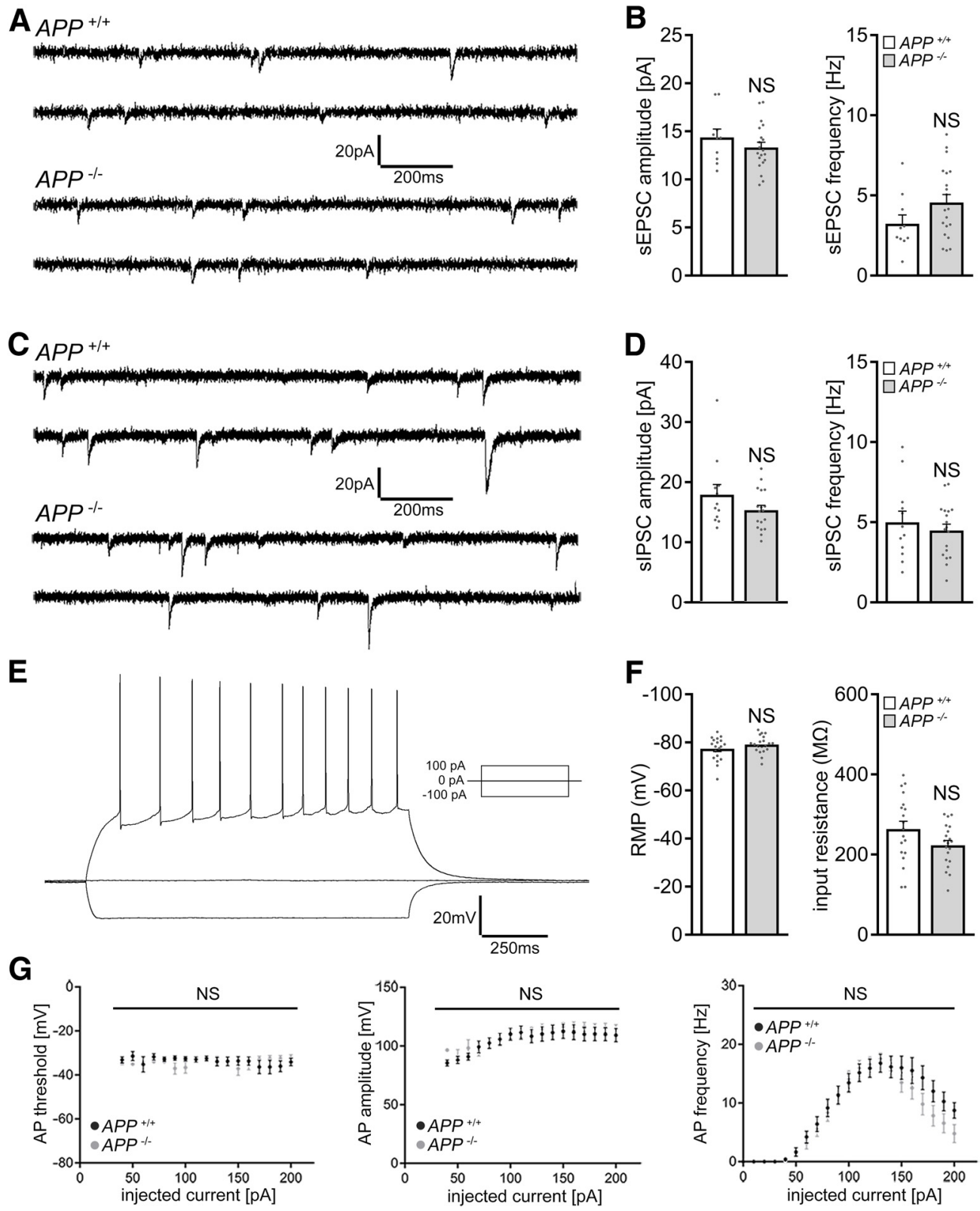

Figure 3. APP deficiency does not affect basic functional properties of cultured dentate granule cells. $A, B$, Sample traces and group data of sEPSCS recorded from dentate granule cells of $A P P^{+/+}$and $A P P^{-1-}$ tissue cultures (APP $P^{+/+}, n=10$ cells from 4 cultures; $A P P^{-/-}, n=20$ cells from 6 cultures; Mann-Whitney test). C, D, Sample traces and group data of sIPSCs from granule cells of $A P P^{+/+}$and $A P P^{-/-}$tissue cultures (APP $P^{+/+}, n=12$ cells from 4 cultures; $A P P^{-/-}, n=18$ cells from 6 cultures; Mann-Whitney test). E-G, Sample traces and group data for input-output properties of dentate granule cells of $A P P^{+/+}$and $A P P^{-1-}$ tissue cultures. RMP, Resting membrane potential; AP, action potential. APP ${ }^{+/+}, n=19$ cells from 5 cultures; $A P P^{-I-}, n=20$ cells from 5 cultures (Mann-Whitney test and two-way ANOVA). Data are mean \pm SEM. NS, Not significant.

the TTX group, while increased mEPSC frequencies were observed in the untreated cultures that were reduced after TTX treatment (Fig. 1I). Increased mEPSC frequencies under control conditions were attributed to viral transduction in these experiments since transfections of APP-deficient preparations with AAV-Syn-Venus resulted in increased mEPSC frequencies without affecting mEPSC amplitudes (amplitude: control, $11.7 \pm 0.3 \mathrm{pA}$; transfected, $11.8 \pm 0.4 \mathrm{pA} ;$ Mann-Whitney test; $p=0.74$; frequency: control, $2.5 \pm 0.2 \mathrm{~Hz}$; transfected, $6.6 \pm 0.7 \mathrm{~Hz}$; MannWhitney test; $p<0.001 ; n=12$ cells from 4 cultures in each group). We conclude from these results that postnatal expression of APP is required for TTX-induced homeostatic scaling of excitatory synapses to occur in cultured dentate granule cells.
Based on our recent work (Lenz et al., 2019), we also tested for changes in inhibitory synaptic strength, and we did not detect TTX-induced changes in mIPSCs of dentate granule cells, either in $\mathrm{APP}^{+/+}$or $A P P^{-/-}$tissue cultures (Fig. 2). Hence, we focused on the role of APP in excitatory synaptic scaling.

No significant alterations in basic functional and structural properties of APP-deficient dentate granule cells

To test whether alterations in baseline synaptic activity explain the inability of $A P P^{-1-}$ granule cells to express homeostatic excitatory synaptic plasticity, sEPSCs and sIPSCs were recorded in a different set of 3-week-old tissue cultures (Fig. $3 A-D$ ). No significant differences between the two genotypes were observed in these experiments. Similarly, the input-output properties of 
A

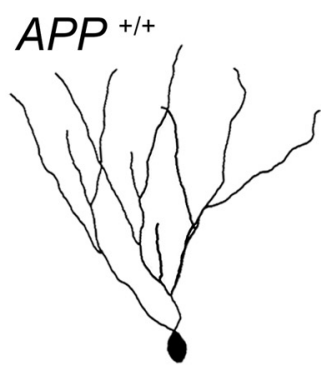

$A P P^{-1-}$

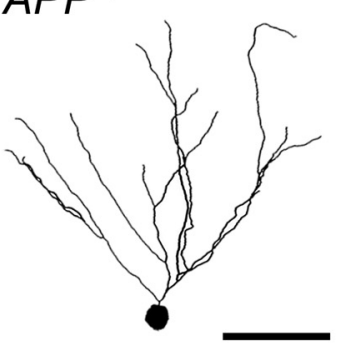

B

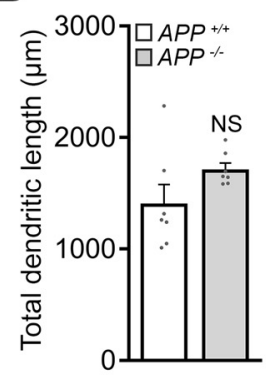

C

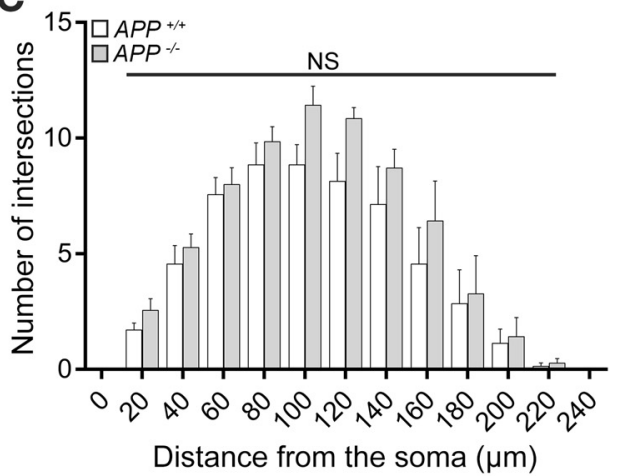

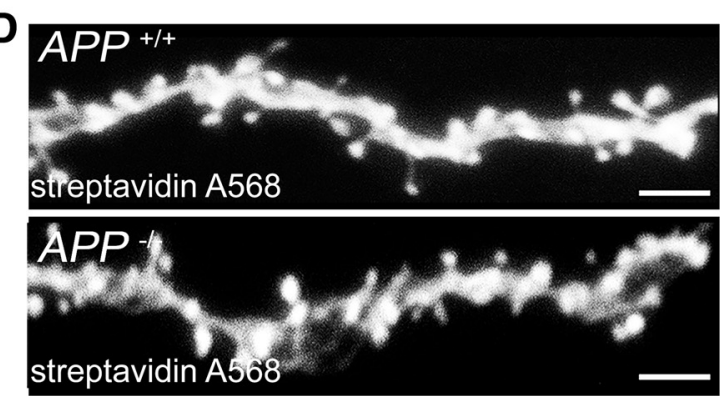

H

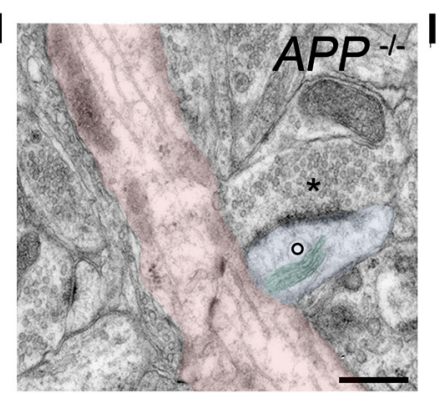

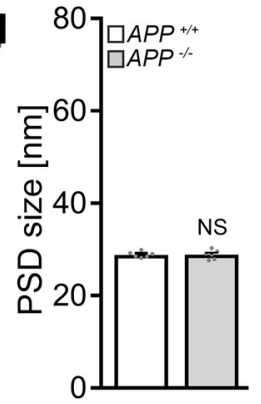

E

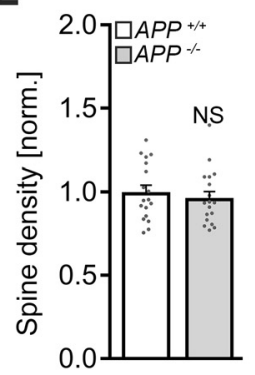

J

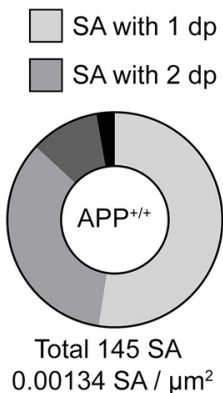

F

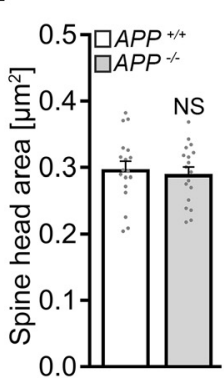

G
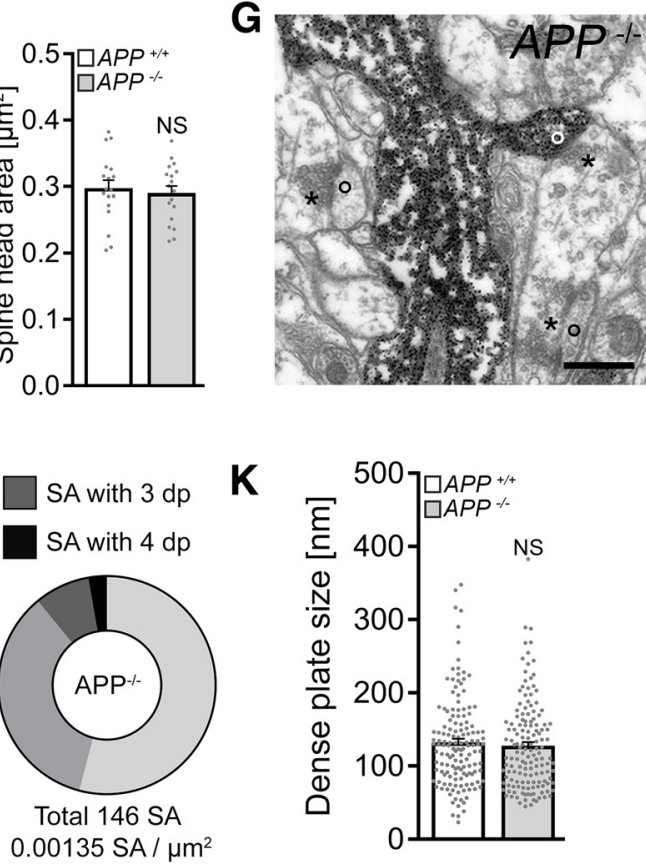

K

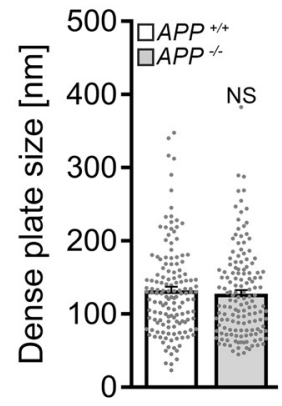

Figure 4. No significant structural differences are observed in granule cells of APP-deficient preparations. A-C, Examples and group data of total dendritic length and Sholl sphere analysis of dentate granule cells in $A P P^{+/+}$and $A P P^{-1-}$ tissue cultures ( $n=7$ cells from 7 cultures per group; Mann-Whitney test and two-way ANOVA). Scale bar, $50 \mu \mathrm{m}$. $\boldsymbol{D}-\boldsymbol{F}$, Spine densities and spine head sizes of dendritic segments in the outer molecular layer (oml). Individual data points indicate mean values per dendritic segment; $\boldsymbol{E}, n=18$ segments from 4 tissue cultures per group; $\boldsymbol{F}$, Mean spine head size per dendritic segment; $n=18$ dendritic segments from 4 tissue cultures per group; Mann-Whitney test. Scale bar, $5 \mu$ m. $\boldsymbol{G}, \boldsymbol{H}$, Electron micrograph of synaptic contacts of $A P P^{-I-}$ dentate granule cells in the oml. Asterisks represent examples of presynaptic compartments. Circles represent postsynapses. Scale bar, $0.5 \mu \mathrm{m}$. $\boldsymbol{H}$, Example of a spine apparatus organelle (SA, green overlay) in a dendritic spine (blue overlay) in the oml of $A P P^{-1-}$ tissue (parent dendrite, red), Scale bar, $0.5 \mu \mathrm{m}$. $I$, Group data of PSD sizes in the oml ( $n=6$ tissue cultures per group; Mann-Whitney test). $\boldsymbol{J}, \boldsymbol{K}$, Analysis of SA cross sections in the oml of $A P P^{+/+}$and $A P P^{-/-}$tissue cultures. Group data for number of $S A s / \mu m^{2}$, number of dense plates (dp), and the dp sizes in cross sections of electron micrographs (APP ${ }^{+/+}, n=145 \mathrm{SA}$ from 6 tissue cultures, total area analyzed 108,251 $\mu \mathrm{m}^{2} ; A P P^{-/-}, n=146 \mathrm{SA}$ from 6 tissue cultures, total area analyzed 108,159 $\mu \mathrm{m}^{2}$; Mann-Whitney test). Data are mean \pm SEM. NS, Not significant.

dentate granule cells (Fig. 3E,F), as well as basic properties of action potentials (Fig. $3 G$ ), were not significantly different between the two groups.

We also tested for variations in basic structural properties of granule cells between $A P P^{+/+}$and $A P P^{-/-}$preparations. As shown in Figure 4, an assessment of total dendritic branch length and Sholl analysis revealed no significant differences between the genotypes (Fig. $4 A-C$ ). We also did not find any significant differences in spine numbers and sizes (Fig. $4 D-F$ ), and synapses were regularly observed in electron microscopy cross-sections of recorded and post hoc stained $A P P^{-1-}$ dentate granule cells (Fig. $4 G$ ). Consistent with our electrophysiological recordings, ultrastructural assessment of postsynaptic densities in the molecular layer of the dentate gyrus did not show any significant differences between the genotypes (Fig. 4H,I). Likewise, no significant differences in the number and sizes of spine apparatus organelles (Gray, 1959; Spacek, 1985; Spacek and Harris, 1997), which have been linked to the ability of neurons to express synaptic plasticity (Deller et al., 2003; Vlachos et al., 2012; Lenz et al., 2021), were observed between $A P P^{-/-}$and $A P P^{+/+}$preparations (Fig. $4 J, K$ ). Hence, basic functional and (ultra)structural alterations do not readily explain the inability of $A P P^{-1-}$ granule cells to scale their excitatory synapses.

A secreted factor rescues the ability of APP-deficient dentate granule cells to express homeostatic synaptic plasticity

In our viral transduction experiments, in which we used flAPP to rescue homeostatic synaptic plasticity of $A P P^{-/-}$granule cells (compare Fig. $1 H, I$ ), we noticed that granule cells not expressing flAPP also showed increased mEPSC amplitudes after TTX 

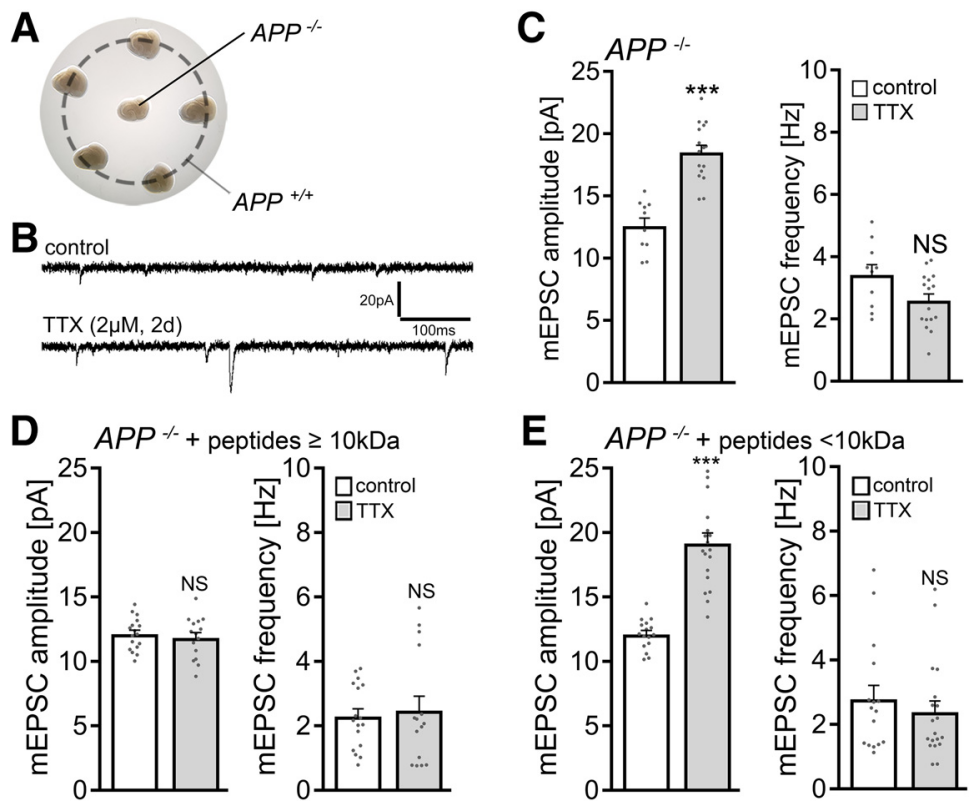

Figure 5. A secreted factor mediates the ability of $A P P^{-/-}$dentate gyrus granule cells to express homeostatic synaptic plasticity. $\boldsymbol{A}$, Example of co-cultured $A P P^{+/+}$and $A P P^{-1-}$ tissue preparations on the same membrane insert. $B, C$, Sample traces and group data of AMPAR-mediated mEPSCs recorded from dentate gyrus granule cells in vehicle-treated (control) and TTX-treated ( $2 \mu \mathrm{m}, 2 \mathrm{~d}$ ) $A P P^{-1-}$ tissue cultures (control, $n=10$ cells from 4 cultures; $\Pi \mathrm{TX}, n=16$ cells from 5 cultures; Mann-Whitney test). $\boldsymbol{D}, \boldsymbol{E}$, Group data of AMPAR-mediated mEPS(s recorded from granule cells in vehicle-treated (control) and TTX-treated $(2 \mu \mathrm{m}, 2 \mathrm{~d}) A P P^{-1-}$ tissue cultures in the presence of WT conditioned medium containing proteins larger $(\boldsymbol{D})$ and smaller $(\boldsymbol{E})$ than $10 \mathrm{kDa}(\boldsymbol{D}$ : control, $n=17$ cells from 5 cultures; TTX, $n=15$ cells from 4 cultures; $E$ : control, $n=16$ cells from 4 cultures; TTX, $n=19$ cells from 4 cultures; Mann-Whitney test). For mEPSC amplitude, one data point is outside the axis limits in the TTX group. Data are mean \pm SEM. NS, Not significant. ${ }^{* *} p<0.001$.

treatment. Thus, we hypothesized that a secreted factor, and not flAPP expression per se, mediates the effects of APP on TTXinduced homeostatic synaptic plasticity.

To test this hypothesis, $A P P^{-1-}$ tissue was cultured with 5 $A P P^{+/+}$cultures on the same membrane insert as shown in Figure $5 \mathrm{~A}$. In these experiments, a significant increase in excitatory synaptic strength was detected in dentate granule cells of TTX-treated $A P P^{-1-}$ cultures (Fig. 5B,C). In an independent round of experiments, culturing medium collected from $A P P^{+/+}$ cultures was concentrated to obtain peptide fractions at a cutoff molecular weight of $10 \mathrm{kDa}$. The medium containing peptides $<10 \mathrm{kDa}$ rescued TTX-induced homeostatic synaptic plasticity in these experiments, while in the presence of conditioned medium with larger peptides no synaptic scaling was observed in $A P P^{-/-}$preparations (Fig. 5D,E). We conclude from these results that a small (i.e., $<10 \mathrm{kDa}$ ) secreted molecular factor originating from $\mathrm{APP}^{+/+}$tissue is sufficient to rescue the ability of granule cells in the $A P P^{-1-}$ cultures to express TTX-induced homeostatic synaptic plasticity. The results of these experiments also indicate that the presence of APP in the target region is not required (i.e., APP per se does not act as a receptor for signaling pathways relevant for TTX-induced excitatory synaptic scaling).

\section{APPs $\alpha$ does not rescue homeostatic synaptic plasticity in APP-deficient preparations}

Previous work revealed that APPs $\alpha$ rescues several phenotypes observed in $A P P^{-1-}$ mice, including alterations in LTP (e.g., Ring et al., 2007; Hick et al., 2015; Fol et al., 2016; Richter et al., 2018). We therefore tested whether APPs $\alpha$ rescues the ability of $A P P^{-I-}$ granule cells to express homeostatic synaptic plasticity in our experiments.
First, $A P P^{-1-}$ cultures were treated with APPs $\alpha$ at a concentration that rescues LTP in acute hippocampal slices (10 nM) (Hick et al., 2015), and TTX-induced synaptic scaling was probed. In these experiments, no homeostatic synaptic adjustment was observed (Fig. 6A,B), thus confirming once more our major finding (i.e., alterations in homeostatic synaptic plasticity of $A P P^{-1-}$ dentate granule cells).

We next resorted to AAV transduction of secreted APPs $\alpha$ (AAV-Syn-T2A-Venus-APPs $\alpha$ ) using the same protocol as described for flAPP (compare Fig. 1H,I). The expression of this viral construct was previously used to successfully rescue LTP defects in $A P P^{-1-}$ mice (Richter et al., 2018). Again, in our experimental setting, no compensatory increase in mean mEPSC amplitude was observed after TTX treatment compared with age- and timematched vehicle-only-treated APPs $\alpha$-transfected $A P P^{-1-}$ tissue cultures (Fig. $6 C, D$ ). An increase in mEPSC frequencies back to baseline was detected in the TTX group in these experiments, indicating complex effects of viral transduction on MEPSC frequencies in the dentate gyrus (Fig. 6D) (see also Lazarevic et al., 2017; Rice et al., 2019). However, viral transduction per se does not rescue the ability of $A P P^{-/-}$granule cells to express homeostatic synaptic plasticity (compare Fig. $1 I$ ).

Finally, tissue cultures from APPs $\alpha$-KI mice were prepared (Ring et al., 2007), which express APPs $\alpha$ constitutively while lacking transmembrane APP and $\mathrm{A} \beta$; this represents another approach for rescuing LTP (Ring et al., 2007). Because in these experiments we also did not observe homeostatic plasticity (Fig. $6 E, F$ ), we conclude that APPs $\alpha$ does not rescue TTX-induced homeostatic synaptic plasticity of dentate granule cells in $A P P^{-/-}$tissue cultures, at least not by using the above-described experimental approaches that all rescue LTP.

\section{Scavenging endogenous APPs $\alpha$ with a specific antibody does not block homeostatic synaptic plasticity}

We next tested for the effects of endogenous APPs $\alpha$ by treating WT tissue cultures with TTX $(2 \mu \mathrm{M} ; 2 \mathrm{~d})$ in the presence of a specific antibody that binds APPs (i.e., the N-terminal APP-E1 domain; JRD32; $1.3 \mu \mathrm{g} / \mathrm{ml}$ ) (Hick et al., 2015). As shown in Figure 7A, a compensatory increase in mEPSC amplitudes was observed in these experiments, thus providing additional evidence that APPs $\alpha$ is not involved in mediating homeostatic synaptic plasticity.

Because treatment with recombinant APPs $\alpha$ (10 nM) also did not cause aberrant "over"-scaling in $A P P^{+/+}$dentate granule cells (Fig. $7 B$ ), together with the experiments conducted in $A P P^{-I-}$ cultures (compare Figs. 5 and 6), we are confident to conclude that APPs $\alpha$ is not a major regulator of homeostatic synaptic plasticity (this study), whereas it does promote LTP (e.g., Ring et al., 2007; Hick et al., 2015; Fol et al., 2016; Richter et al., 2018).

\section{A $\beta$ rescues homeostatic synaptic plasticity in APP-deficient preparations}

We then considered the amyloidogenic processing pathway and the potential for $\mathrm{A} \beta$ involvement in mediating homeostatic synaptic 
plasticity. Another set of $A P P^{-1-}$ tissue cultures was treated for $2 \mathrm{~d}$ with 2 $\mu \mathrm{M}$ TTX and with a synthetic A $\beta$ protein fragment 1-42 (1.5 $\mu \mathrm{M})$ (Novotny et al., 2016). Notably, a full-sized homeostatic synaptic scaling response was observed in these experiments (Fig. 8A): in the presence of $\mathrm{A} \beta_{1-42}$, mEPSC amplitudes increased from $10.9 \pm 0.5 \mathrm{pA}$ to $16.8 \pm 0.9 \mathrm{pA}$ after 2 d TTX treatment $(p<0.001$; KruskalWallis test followed by Dunn's post hoc test). Because similar experiments with the synthetic inverse $\mathrm{A} \beta$ protein fragment $42-1(1.5 \mu \mathrm{M})$ did not show any significant changes in mEPSC properties (Fig. $8 B$ ), we conclude that the application of exogenous $\mathrm{A} \beta_{1-42}$ rescues TTX-induced homeostatic synaptic plasticity in $A P P^{-1-}$ preparations.

We also explored possible dosedependent effects of $\mathrm{A} \beta_{1-42}$ at concentrations of $0.5 \mu \mathrm{M}, 200 \mathrm{nM}$, and 200 рм (compare Puzzo et al., 2008), and we found comparable TTXinduced synaptic strengthening at all concentrations tested (Fig. 8A). Moreover, increased mEPSC amplitudes were also observed in the presence of $\mathrm{A} \beta_{1-40}(1.5 \mu \mathrm{M}$; Fig. $8 D)$. We conclude from these results that exogenous $\mathrm{A} \beta$ rescues the ability of $A P P^{-/-}$dentate granule cells to express homeostatic synaptic plasticity.

\section{Pharmacological inhibition of} $\beta$-secretases in WT tissue cultures blocks homeostatic synaptic plasticity Next, we sought to test for the role of endogenous $\mathrm{A} \beta$ on homeostatic synaptic plasticity. Because $\mathrm{A} \beta$ is produced by sequential cleavage of APP by $\beta$ - and $\gamma$-secretases (Chow et al., 2010; Zheng and Koo, 2011), we hypothesized that pharmacological inhibition of $\beta$-secretases (i.e., blocking the first step of the amyloidogenic processing pathway) should impede the ability of WT dentate granule cells to express TTX-induced synaptic scaling. Accordingly, WT cultures were treated with TTX $(2 \mu \mathrm{m} ; 2 \mathrm{~d})$ and with BACE inhibitor C3 (20 $\mu \mathrm{M} ; 2 \mathrm{~d})$ (Stachel et al., 2004). Pharmacological inhibition of $\beta$-secretases had no apparent effect on baseline mEPSC recordings, and a TTXinduced increase in mEPSC amplitudes was not observed. Exposure to $\mathrm{A} \beta_{1-42}(1.5 \mu \mathrm{M})$ together with $\mathrm{BACE}$ inhibitor $\mathrm{C} 3$ restored the ability of WT dentate granule cells to express homeostatic synaptic scaling (Fig. 9A). Furthermore, in the presence of BACE inhibitor C3, TTX-induced synaptic scaling was not observed in $A P P^{-/-}$preparations co-cultured with 5 $A P P^{+/+}$cultures on the same membrane insert (Fig. $9 B$; compare Fig. 5). These results suggest that $\mathrm{APP} / \mathrm{A} \beta$ is part of an endogenous signaling pathway that mediates homeostatic synaptic plasticity.
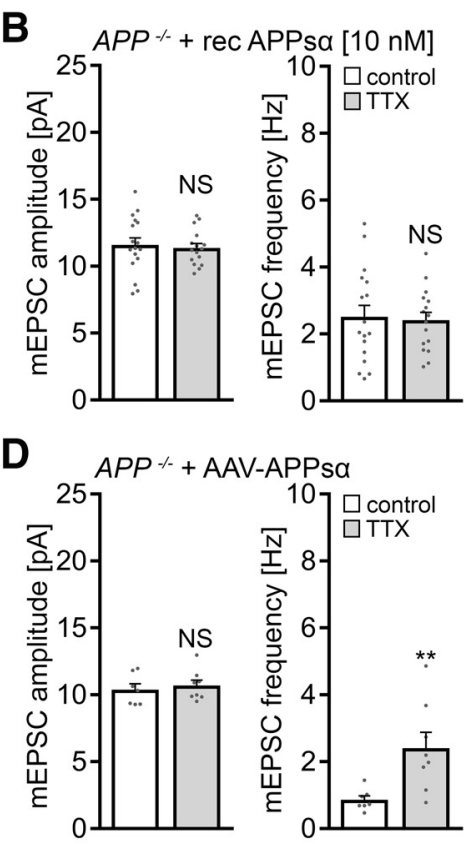

$\mathbf{F}$

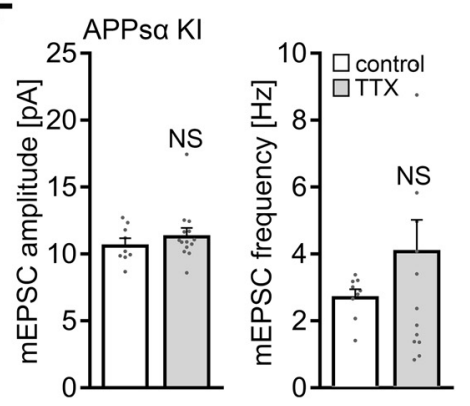

Figure 6. APPs $\alpha$ does not rescue the ability of APP-deficient dentate granule cells to express homeostatic synaptic plasticity. $A, B$, Sample traces and group data of AMPAR-mediated mEPSCs recorded from granule cells in vehicle-treated (control) and

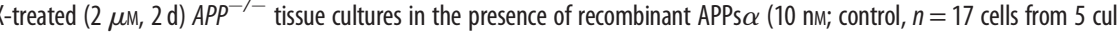
from , 16 cells from 5 cultures; Mann-Whitney test). C, D, Sample traces and group data of AMPAR-mediated mEPSCs 14 cells from 4 cultures; Mann-Whitney test). For mEPSC frequency, one data point is outside the axis limits in the TTX group. Data are mean \pm SEM. NS, Not significant. ${ }^{* *} p<0.01$.

Pharmacological inhibition of $\gamma$-secretases in WT tissue cultures blocks homeostatic synaptic plasticity

BACE not only cleaves APP but also targets several other substrates in the nervous system (Barao et al., 2016). Although $\mathrm{A} \beta_{1-42}$ rescued homeostatic synaptic plasticity in BACE inhibitor C3-treated WT cultures, we decided to err on the side of caution. Accordingly, another series of experiments was conducted using the $\gamma$-secretase inhibitor Begacestat (GSI-953; $1 \mu \mathrm{M}$ ) (Martone et al., 2009) to block the second enzymatic step of the amyloidogenic processing pathway. As shown in Figure 9C, a compensatory increase in mEPSC amplitudes was not observed in the presence of Begacestat after TTX treatment. Again, A $\beta_{1-42}(1.5 \mu \mathrm{M})$ rescued the ability of WT dentate granule cells to express homeostatic synaptic plasticity in the presence of the $\gamma$-secretase inhibitor (Fig. 9C). Consistent with these findings, $\mathrm{A} \beta$ sandwich-ELISA confirmed that endogenous $\mathrm{A} \beta_{1-40}$ and $\mathrm{A} \beta_{1-42}$ are significantly reduced by pharmacological inhibition of $\beta$ - or $\gamma$-secretases in our experimental setting (Fig. 9D) 

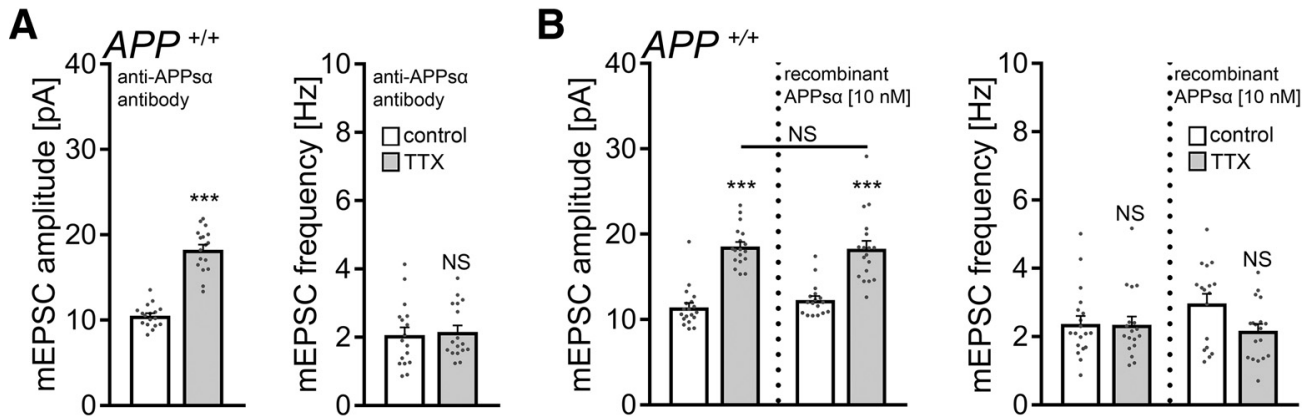

Figure 7. APPs $\alpha$ has no apparent effect in TTX-induced homeostatic plasticity of WT dentate granule cells. $A$, Group data of AMPAR-mediated mEPSCs recorded from granule cells in vehicle-treated (control) and TTX-treated ( $2 \mu \mathrm{m}, 2 \mathrm{~d}) \mathrm{APP}^{+/+}$tissue cultures in the presence of a specific anti-APPs $\alpha$ antibody (JRD32; $1.3 \mu \mathrm{g} / \mathrm{ml} ; n=17$ cells from 6 cultures per group; MannWhitney test). B, Recombinant APPs $\alpha$ (10 nM) does not cause aberrant "over"-scaling of APP ${ }^{+/+}$dentate granule cells (control, $n=19$ cells from 7 cultures; TTX, $n=18$ cells from 6 cultures; APPs $\alpha, n=17$ cells from 6 cultures; TTX + APPs $\alpha, n=18$ cells from 6 cultures). Data are mean \pm SEM. NS, Not significant. ${ }^{* *} p<0.001$ (Kruskal-Wallis test followed by Dunn's post hoc test).
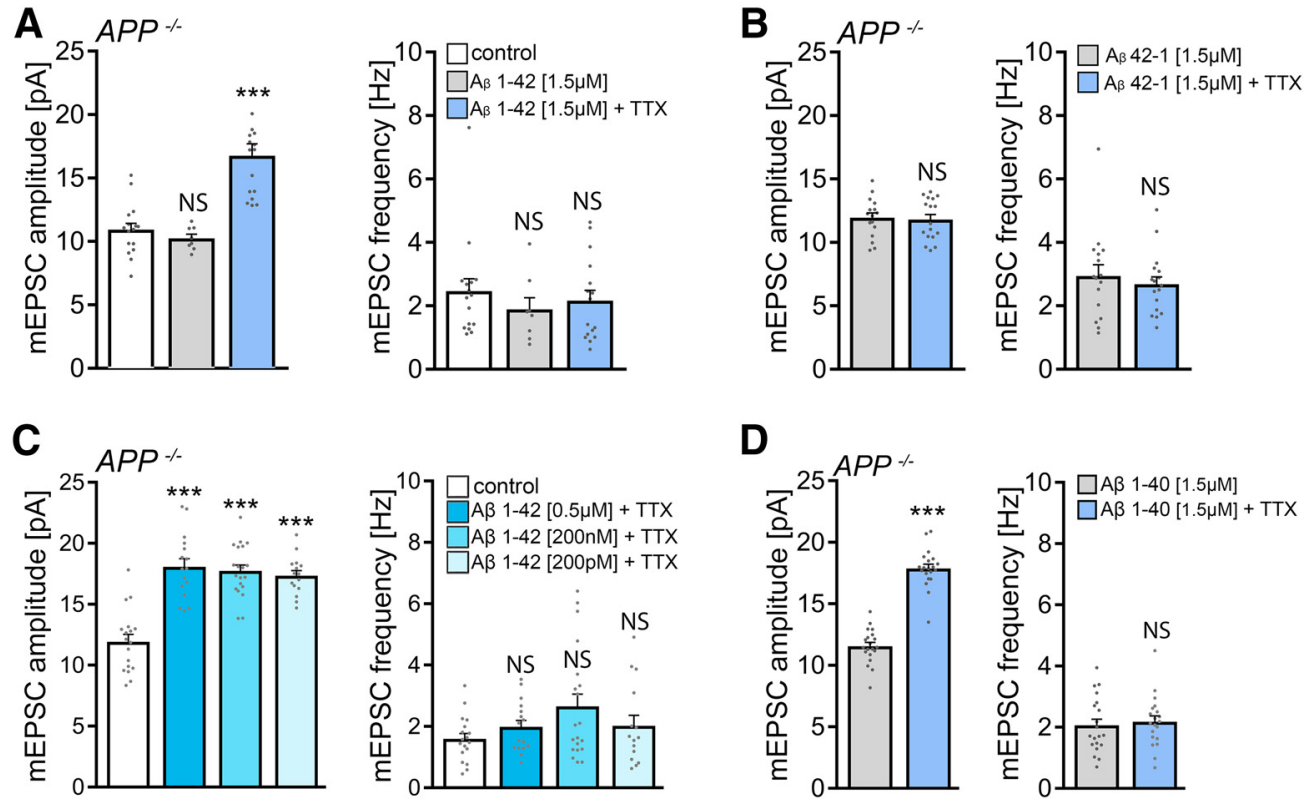

Figure 8. Amyloid- $\beta_{1-42}$ rescues the ability of APP-deficient dentate granule cells to express homeostatic synaptic plasticity. $A, B$, Group data of AMPAR-mediated mEPSCS recorded from granule cells in vehicle-treated (control) and TTX-treated $(2 \mu \mathrm{M}, 2 \mathrm{~d}) A P P^{-1-}$ tissue cultures in the presence of amyloid- $\beta_{1-42}\left(\mathrm{~A} \beta_{1-42 ;} ; .5 \mu \mathrm{M}, \boldsymbol{A}\right)$ or $\mathrm{A} \beta_{42-1}(1.5 \mu \mathrm{M}, \boldsymbol{B})$. $\boldsymbol{A}, \mathrm{Control}, n=16$ cells from 4 cultures; $A \beta_{1-42}, n=8$ cells from 3 cultures; $A \beta_{1-42}+$ TTX, $n=16$ cells from 5 cultures; Kruskal-Wallis test followed by Dunn's post hoc test; for mEPSC amplitudes, one data point is outside the axis limits in the $A \beta_{1-42}+$ TTX group. $B, A \beta_{42-1}, n=16$ cells from 4 cultures; $A \beta_{42-1}+$ TTX, $n=17$ cells from 5 cultures; Mann-Whitney test. $C$, Group data of AMPAR-mediated mEPSCs recorded from granule cells in vehicle-treated (control) and TTX-treated $\left(2 \mu \mathrm{m}, 2 \mathrm{~d}\right.$ ) APP ${ }^{-1-}$ tissue cultures in the presence of $0.5 \mu \mathrm{m}, 200 \mathrm{~nm}$, and $200 \mathrm{pm}$ of $\mathrm{A} \beta_{1}$ ${ }_{42}$ (control, $n=18$ cells from 5 cultures; $0.5 \mu \mathrm{M} \mathrm{A} \beta_{1-42}+$ TTX, $n=16$ cells from 4 cultures; $200 \mathrm{~nm} \mathrm{~A} \beta_{1-42}+$ TTX, $n=20$ cells from 6 cultures; $200 \mathrm{pm} \mathrm{A} \beta_{1-42}+$ TTX, $n=15$ cells from 4 cultures; Kruskal-Wallis test followed by Dunn's post hoc test). $D$, Group data of AMPAR-mediated mEPSCs recorded from APP ${ }^{-1-}$ granule cells in the presence of $1.5 \mu \mathrm{M} \mathrm{A} \beta_{1-40}(n=20$ cells from 6 cultures in each group; Mann-Whitney test). Data are mean \pm SEM. NS, Not significant. ${ }^{* *} p<0.001$.

Scavenging endogenous $\mathrm{A} \beta$ with a specific antibody blocks homeostatic synaptic plasticity in WT tissue cultures

Finally, we conducted experiments in WT cultures using an antibody that binds endogenous $\mathrm{A} \beta$ (anti-A $\beta_{11-28}$; $\mathrm{BNT77} ; 1.3$ $\mu \mathrm{g} / \mathrm{ml}$ ) (Hashimoto et al., 2010). No significant differences in mEPSC properties between vehicle-only and TTX-treated WT dentate granule cells were observed in these experiments (Fig. $10 A)$. Similarly, in the experimental setting in which $A P P^{-1-}$ tissue was co-cultured with $A P P^{+/+}$cultures, again, no TTXinduced synaptic scaling was observed in the $A P P^{-1-}$ cultures in the presence of the anti-A $\beta$ antibody (control, $10.5 \pm 0.3 \mathrm{pA}$; TTX, 9.9 $\pm 0.2 \mathrm{pA}$; Mann-Whitney test; $p=0.09 ; n=16$ cells from 4 cultures in each group; compare Fig. 5). We also tested for the effects of exogenous $\mathrm{A} \beta_{1-42}(1.5 \mu \mathrm{M})$ on TTX-induced homeostatic synaptic plasticity in WT preparations and found no signs for aberrant "over"-scaling (Fig. 10B) (compare Gilbert et al., 2016). Consistent with earlier reports, a reduction in mEPSC amplitudes was observed in $\mathrm{A} \beta_{1-42}$ treated controls (Fig. 10B) (Chang et al., 2006; Gilbert et al., 2016).

Together, we conclude that APP is a key regulator of homeostatic synaptic plasticity and that $\mathrm{A} \beta$-dependent signaling pathways account for the ability of cultured dentate granule cells to express TTX-induced homeostatic plasticity of excitatory synapses.

Pharmacological inhibition of NMDARs rescues homeostatic synaptic plasticity in APP-deficient preparations

What are the downstream signaling pathways of APP/A $\beta$-mediated homeostatic synaptic plasticity? Previous work revealed that $\mathrm{A} \beta$ affects Hebbian plasticity via modulation of NMDARs 
A
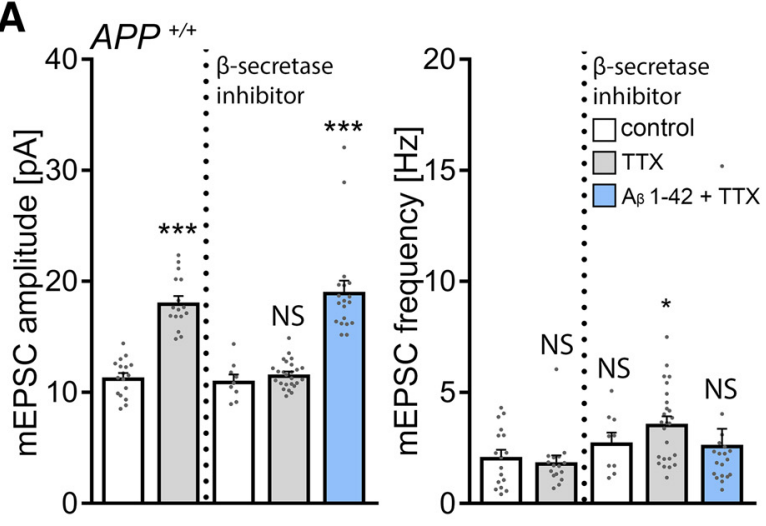

B

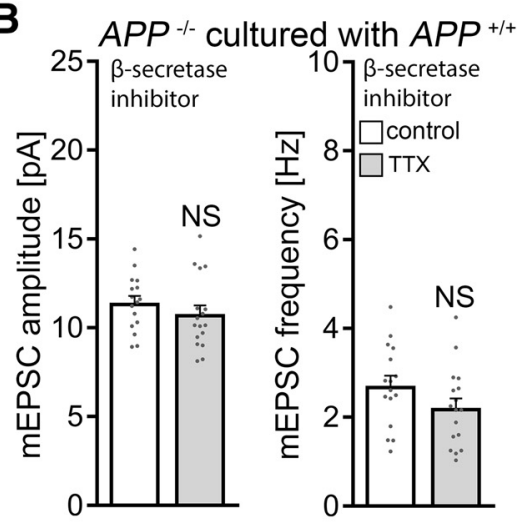

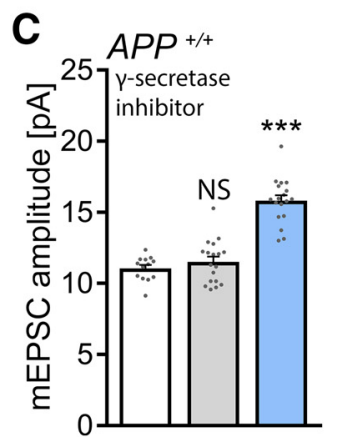

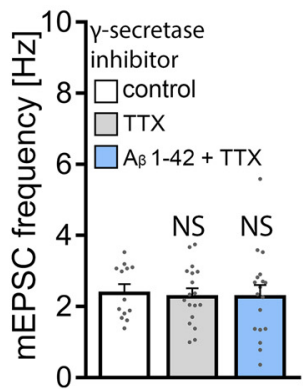

D
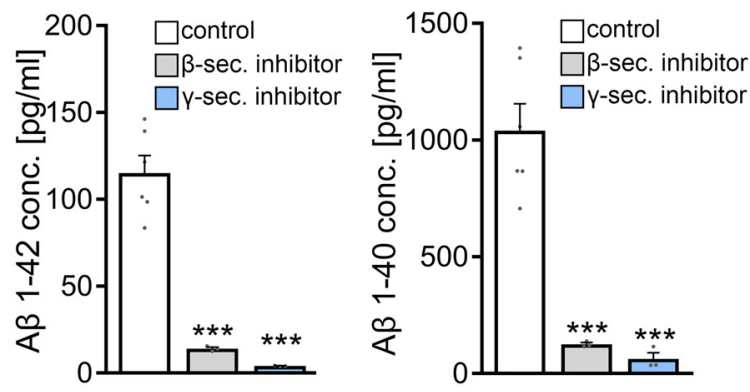

Figure 9. Pharmacological inhibition of $\beta$ - or $\gamma$-secretases blocks homeostatic synaptic plasticity. $\boldsymbol{A}$, Group data of AMPAR-mediated mEPSCs recorded from granule cells in vehicle-treated (control) and TTX-treated $(2 \mu \mathrm{m}, 2 \mathrm{~d})$ WT tissue cultures. BACE inhibitor $\mathrm{C} 3(20 \mu \mathrm{m})$ prevents TTX-induced synaptic scaling, an effect that is reversed in the presence of $\mathrm{A} \beta_{1-42}(1.5 \mu \mathrm{m})$. Untreated: control, $n=17$ cells from 5 cultures; TTX, $n=16$ cells from 4 cultures. $\beta$-secretase inhibitor: control, $n=9$ cells from 3 cultures; TTX, $n=25$ cells from 7 cultures; A $\beta_{1-42}+$ TTX, $n=19$ cells from 5 cultures; Kruskal-Wallis test followed by Dunn's post hoc test. $\boldsymbol{B}$, Group data of AMPAR-mediated mEPSCs recorded from granule cells in vehicle-treated (control) and TTXtreated $(2 \mu \mathrm{m}, 2 \mathrm{~d}) A P P^{-I-}$ preparations co-cultured with $A P P^{+/+}$tissue (compare Fig. 5). BACE inhibitor C3 (20 $\left.\mu \mathrm{m}\right)$ prevents TTX-induced synaptic scaling (control, $n=16$ cells from 5 cultures; TTX, $n=17$ cells from 5 cultures; Mann-Whitney test). C, Pharmacological inhibition of $\gamma$-secretases with Begacestat (1 $\mu \mathrm{m})$ prevents TTX-induced synaptic scaling of dentate granule cells in WT tissue cultures, an effect that is reversed in the presence of $A \beta_{1-42}(1.5 \mu \mathrm{m})$. Control, $n=13$ cells from 4 cultures; TTX, $n=18$ cells from 6 cultures; $A \beta \beta_{1-42}+$ TTX, $n=18$ cells from 6 cultures; Kruskal-Wallis test followed by Dunn's post hoc test. $D$, Concentrations of $A \beta_{1-42}$ and $A \beta_{1-40}$ in culturing medium collected from vehicle-treated (control), BACE inhibitor (3treated $\left(\beta\right.$-sec. inhibitor), and Begacestat-treated ( $\gamma$-sec. inhibitor) $A P P^{+/+}$tissue cultures $(n=3-6$ wells per group; one-way ANOVA). Data are mean \pm SEM. NS, Not significant. ${ }^{*} p<0.05 .{ }^{* * *} p<0.001$

(Chen et al., 2002; Snyder et al., 2005; Zhang et al., 2009). Considering the role of NMDARs in homeostatic synaptic plasticity (i.e., NMDAR inhibition triggers synaptic up-scaling) (Sutton et al., 2006), we hypothesized that A $\beta$ may trigger AMPAR-mediated homeostatic synaptic plasticity by modulating NMDARs.

To test for the effects of $A \beta$ on NMDARs in our experiments, NMDAR-mediated mEPSCs were recorded from $A P P^{-/-}$dentate granule cells at a holding potential $+40 \mathrm{mV}$, and $\mathrm{A} \beta_{1-42}(1.5$ $\mu \mathrm{M})$ was washed into the recording chamber. A significant reduction in NMDAR-mediated mEPSC amplitudes was observed in these experiments (Fig. 11A). Based on these results, we speculated that pharmacological inhibition of NMDARs could rescue the ability of $A P P^{-/-}$dentate granule cells to express TTX-induced synaptic scaling. Indeed, in the presence of the NMDAR antagonist D-APV $(50 \mu \mathrm{M})$, a significant increase in AMPAR-mediated mEPSC amplitudes was noted in TTXtreated $A P P^{-1-}$ preparations, consistent with a compensatory (i.e., homeostatic) synaptic response (Fig. 11B). In a separate experiment, baseline recordings of NMDAR-mediated mEPSCs showed no significant differences between untreated $A P P^{-/-}$ and $A P P^{+/+}$granule cells $\left(A P P^{+/+}, 17.6 \pm 0.7 \mathrm{pA} ; A P P^{-/-}\right.$, $17.0 \pm 0.6 \mathrm{pA} ; n=9$ and $n=10$ cells, respectively; $p=0.66$; Mann-Whitney test), confirming once more that basic functional differences between the two genotypes do not trivially explain our major findings (compare Figs. 3 and 4).
Pharmacological inhibition of CaMKII rescues homeostatic synaptic plasticity in APP-deficient preparations

A $\beta$ has been linked to inactivation of CaMKII (Zhao et al., 2004; Townsend et al., 2007; Gu et al., 2009; but see Opazo et al., 2018). Hence, we reasoned that, in the absence of $\mathrm{APP} / \mathrm{A} \beta$, pharmacological inhibition of CaMKII might also rescue TTX-induced synaptic scaling. Indeed, increased mEPSC amplitudes were observed in $A P P^{-1-}$ cultures after TTX treatment in the presence of KN-93 $(5 \mu \mathrm{M})$, but not with the inactive analog KN-92 (5 $\mu \mathrm{M}$; Fig. 11C). Hence, NMDAR-mediated CaMKII-dependent downstream signaling pathways seem to be involved in $\mathrm{APP} / \mathrm{A} \beta$ mediated homeostatic synaptic plasticity.

\section{Role of synaptopodin in APP/A $\beta$-mediated homeostatic synaptic plasticity}

In previous work, we demonstrated that the actin-binding molecule synaptopodin, which is a marker and essential component of the $\mathrm{Ca}^{2+}$-storing spine apparatus organelle (Deller et al., 2003), is required for the expression of homeostatic synaptic plasticity (Vlachos et al., 2013). In this context, a $\mathrm{Ca}^{2+}$-dependent compensatory increase in synaptopodin clusters was observed, consistent with a negative feedback mechanism that mediates homeostatic synaptic plasticity (Vlachos et al., 2013). Notably, an association between synaptopodin and peptides corresponding to $\mathrm{CaMKII} \alpha$ and $\mathrm{CaMKII} \beta$ has been recently reported (Konietzny et al., 2019). 

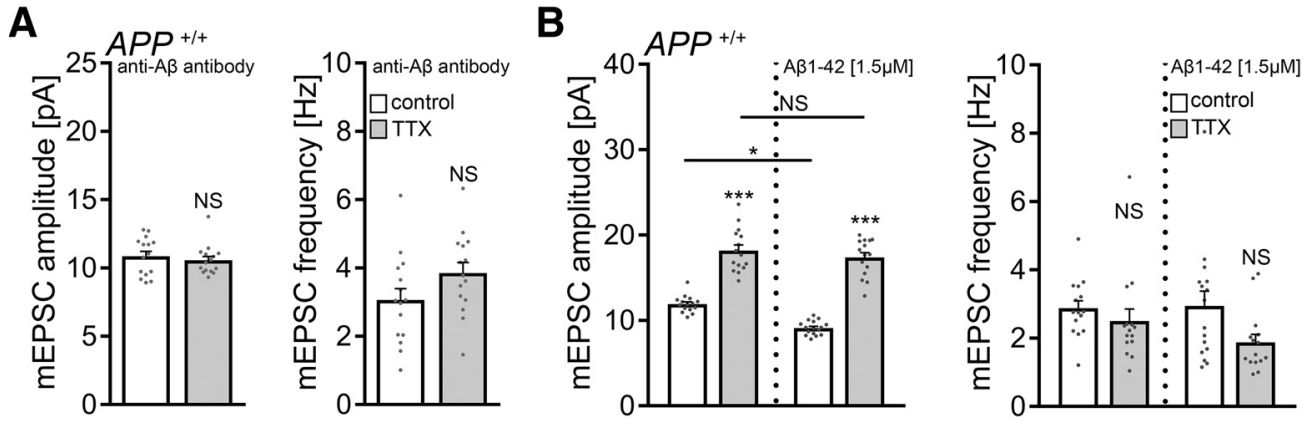

Figure 10. Endogenous $A \beta$ is required for the expression of homeostatic synaptic plasticity. $A$, Group data of AMPAR-mediated mEPSCs recorded from granule cells in vehicle-treated (control) and TTX-treated ( $2 \mu \mathrm{m}, 2 \mathrm{~d}$ ) APP ${ }^{+/+}$tissue cultures in the presence of a specific anti-A $\beta$ antibody (BNT-77; $1.3 \mu \mathrm{g} / \mathrm{ml} ; n=15$ cells from 5 cultures in each group; Mann-Whitney test). $B$, Group data of AMPAR-mediated mEPSCs recorded from granule cells in vehicle-treated (control) and TTX-treated $(2 \mu \mathrm{m}, 2 \mathrm{~d}) A \mathrm{AP}^{+/+}$tissue cultures in the presence of $\mathrm{A} \beta_{1-42}(1.5 \mu \mathrm{m})$. $\mathrm{A} \beta_{1-42}$ does not cause aberrant "over"-scaling (compare with Fig. 7; untreated group: $n=15$ cells from 5 cultures in each group; $\mathrm{A} \beta_{1-42}$ [1.5 $\mu \mathrm{m}$ ] treated group: control, $n=16$ cells from 5 cultures; TTX, $n=15$ cells from 5 cultures; Kruskal-Wallis test followed by Dunn's post hoc test). Data are mean \pm SEM. NS, Not significant. ${ }^{*} p<0.5$. ${ }^{* * *} p<0.001$.

To test whether activity-dependent changes of synaptopodin are part of a negative feedback mechanism that requires APP/ $\mathrm{A} \beta$-dependent signaling, $A P P^{-1-}$ cultures were once again treated with TTX $(2 \mu \mathrm{M} ; 2 \mathrm{~d})$. Immunostained synaptopodin clusters were assessed in the outer molecular layer of the dentate gyrus (Fig. $11 D-F$ ), and the previously reported compensatory increase in synaptopodin cluster sizes was not observed in TTXtreated $A P P^{-I-}$ cultures (Fig. 11G) (compare Vlachos et al., 2013). We then tested whether, in the presence of $A \beta_{1-42}$ $(1.5 \mu \mathrm{M})$, TTX-induced changes in synaptopodin clusters are triggered. Indeed, the same protocol that rescues homeostatic synaptic plasticity in $A P P^{-1-}$ preparations also induces synaptopodin changes similar to that observed in WT cultures (Fig. 11G).

Does pharmacological inhibition of NMDARs and CaMKII rescue homeostatic changes in synaptopodin clusters of $A P P^{-/-}$ cultures? As shown in Figure 11G, in the presence of D-APV (50 $\mu \mathrm{M})$ or KN93 $(5 \mu \mathrm{M})$, a significant increase in synaptopodin clusters was observed in response to TTX $(2 \mu \mathrm{M}, 2 \mathrm{~d})$. These results indicate that $\mathrm{APP} / \mathrm{A} \beta$ is part of a $\mathrm{Ca}^{2+}$-dependent negative feedback mechanism that regulates synaptopodin cluster properties in an NMDAR- and CaMKII-dependent manner.

Finally, based on the observation that $\mathrm{A} \beta_{1-42}$ rescues TTXinduced homeostatic synaptic plasticity, we tested for the effects of A $\beta_{1-42}$ in synaptopodin-deficient dentate granule cells, which do not form spine apparatus organelles and show defects in homeostatic synaptic plasticity (Vlachos et al., 2013). Whereas the previously reported deficit in TTX-induced homeostatic synaptic plasticity was reproduced in these experiments, $\mathrm{A} \beta_{1-42}$ did not rescue homeostatic synaptic plasticity in $S Y N P O^{-1-}$ dentate granule cells (Fig. 11H). Together, we propose that synaptopodin is one of the downstream molecular targets required for APP/ A $\beta$-mediated homeostatic synaptic plasticity (Fig. 11I).

\section{Discussion}

We regard the significant finding of this study to be the discovery of a previously unknown APP/A $\beta$ phenotype that becomes salient after network activity is altered (i.e., blocked by TTX for a prolonged period of time). Under these conditions, $A P P^{-1-}$ dentate granule cells do not scale their excitatory synapses in a homeostatic manner. Surprisingly, this plasticity phenotype does not depend on APPs $\alpha$, which is generated from APP via nonamyloidogenic processing and which has been linked to Hebbian plasticity, but on $\mathrm{A} \beta$, which is generated from APP via processing along the amyloidogenic pathway. Consistent with this observation, pharmacological inhibition of $\beta$ - and $\gamma$-secretases as well as scavenging endogenous $\mathrm{A} \beta$ with antibodies blocked TTX-induced synaptic scaling in WT tissue cultures. A $\beta$-dependent synaptic scaling required modulation of downstream $\mathrm{Ca}^{2+}$-dependent signaling pathways, including NMDARs and CaMKII, as well as synaptopodin, a molecule essential for the formation of the $\mathrm{Ca}^{2+}$-storing spine apparatus. Together, these results reveal a direct involvement of amyloidogenic APP processing and $\mathrm{A} \beta$ in homeostatic synaptic plasticity. This involvement raises the intriguing possibility that changes in the balance of APP processing along the two major APP-processing pathways could also lead to changes in the balance of Hebbian and homeostatic plasticity in the brain (compare Galanis and Vlachos, 2020).

Studies using mouse mutants lacking APP or APP-gene family members have established a firm link between APP and the ability of neurons to express synaptic plasticity (Müller et al., 2017). Specifically, the ability of neurons to express LTP of excitatory neurotransmission is impaired in aged $A P P^{-1-}$ mice (e.g., Dawson et al., 1999; Seabrook et al., 1999; Ring et al., 2007; Tyan et al., 2012). APPs $\alpha$ could rescue these deficits (e.g., Ring et al., 2007; Hick et al., 2015; Fol et al., 2016; Richter et al., 2018) using recombinant, viral, and genetic strategies, suggesting a "plasticity-promoting" role of APP via the non-amyloidogenic processing pathway (Mockett et al., 2017).

Based on these observations, we assumed that another major form of synaptic plasticity (i.e., homeostatic synaptic plasticity) (Turrigiano et al., 1998) could also depend on APP or one of its diverse processing products. Indeed, $A P P^{-1-}$ neurons failed to scale their synapses after TTX treatment, implicating APP in homeostatic plasticity, but APPs $\alpha$ could not rescue this APP-dependent plasticity phenotype. Similarly, scavenging endogenous APPs $\alpha$ or treatment with recombinant APPs $\alpha$ did not affect TTX-induced homeostatic synaptic plasticity in WT dentate granule cells. This phenomenon cannot be trivially explained by an inability of dentate granule cells to respond to APPs $\alpha$ because the exogenous application of APPs $\alpha$ robustly enhances LTP in these neurons (Taylor et al., 2008). Together, these observations suggest that the plasticity-promoting effect of APPs $\alpha$ (Mockett et al., 2017) should be narrowed down and specified: APP processing via the non-amyloidogenic pathway promotes the ability of neurons to express LTP, but not necessarily all forms of synaptic plasticity because our data demonstrate that APPs $\alpha$ is not a key regulator of homeostatic synaptic plasticity.

The inability to rescue homeostatic plasticity via APPs $\alpha$ (compare Fig. 6) raised the intriguing possibility that APP 

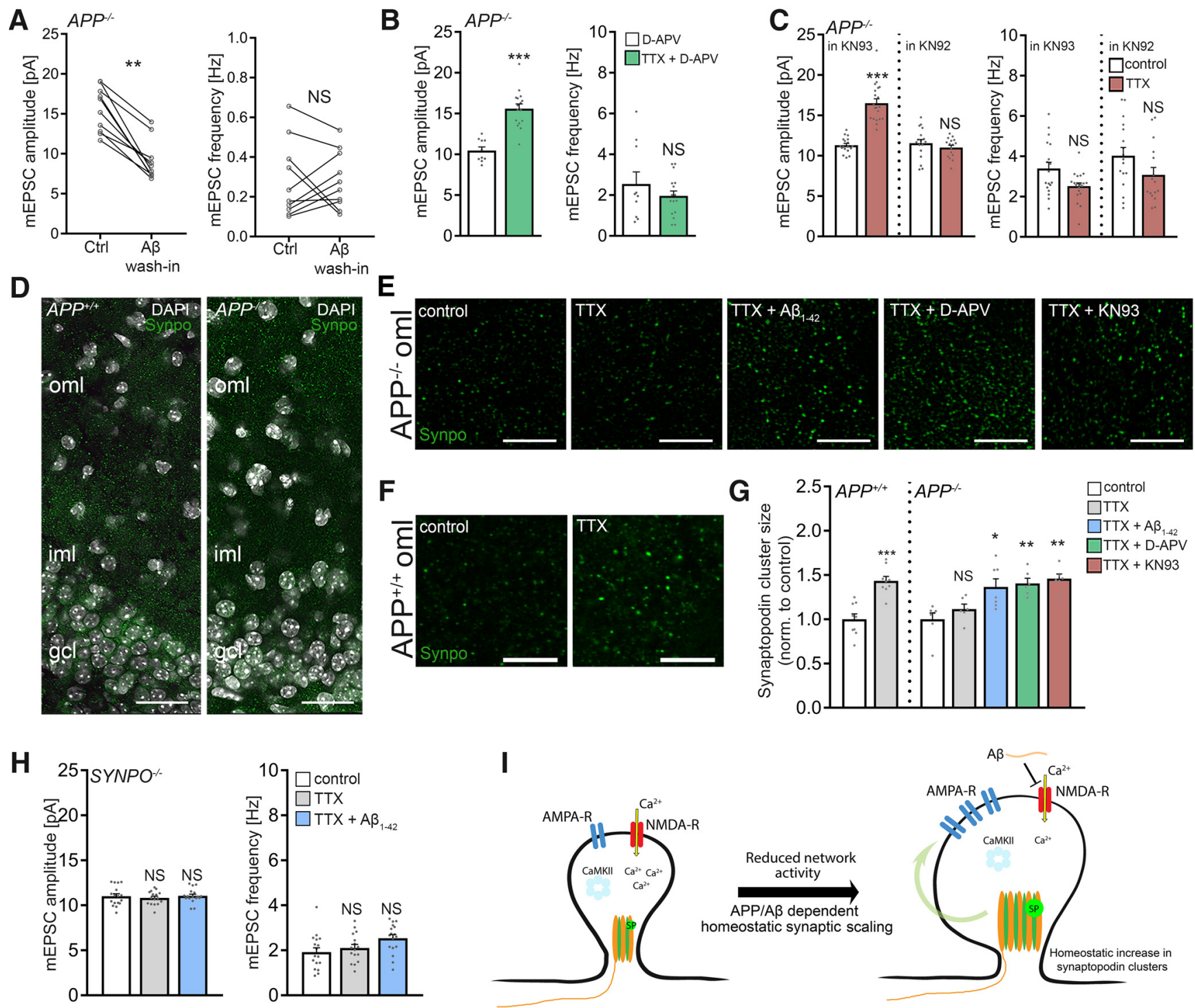

Figure 11. Role of $\mathrm{Ca}^{2+}$ signaling and synaptopodin in APP/amyloid- $\beta$-mediated homeostatic synaptic scaling. $\boldsymbol{A}$, Group data of NMDAR-mediated mEPSCS recorded from APP ${ }^{-/-}$dentate granule cells before and after washing $\mathrm{A} \beta_{1-42}(1.5 \mu \mathrm{m})$ into the recording chamber ( $n=10$ cells from 5 tissue cultures; Wilcoxon test). $\boldsymbol{B}$, Group data of AMPAR-mediated mEPSCs recorded from granule cells in D-APV (50 $\mu \mathrm{m} ; 2 \mathrm{~d}$ )-treated and D-APV $(50 \mu \mathrm{m})+$ TTX-treated $(2 \mu \mathrm{m}, 2 \mathrm{~d})$ APP ${ }^{-1-}$ tissue cultures (D-APV, $n=10$ cells from 3 cultures; TTX + D-APV, $n=16$ cells from 4 cultures; Mann-Whitney test). C, Group data of AMPAR-mediated mEPSCs from granule cells in APP ${ }^{-1-}$ cultures recorded in the presence of the CaMKII inhibitor KN93 or the inactive analog KN92 (KN93: control, $n=18$ cells from 5 cultures; TTX, $n=20$ cells from 5 cultures; KN92: control, $n=17$ cells from 5 cultures; TTX $=n=16$ cells from 5 cultures; Mann-Whitney test). D, Example of $\mathrm{APP}^{+/+}$and $\mathrm{APP}^{-/-}$tissue cultures immunostained for synaptopodin (Synpo, green). Cluster sizes were assessed in the outer molecular layer (oml) of the dentate gyrus. iml, Inner molecular layer; gcl, granule cell layer. DAPI, nuclear stain. Scale bar, $50 \mu \mathrm{m}$. E, $F$, Examples of analyzed visual fields (six fields per culture and condition) at higher magnification. All treatments $2 \mathrm{~d}$. TTX, $2 \mu \mathrm{m} ; \mathrm{A} \beta_{1-42}, 1.5 \mu \mathrm{m}$; D-APV, $50 \mu \mathrm{m}$, KN93, $5 \mu \mathrm{m}$. Scale bar, $5 \mu \mathrm{m}$. G, Group data of synaptopodin cluster sizes in the respective groups. Values normalized to controls $\left(\right.$ APP $^{+/+} n=9$ cultures per group; APP ${ }^{-/-}$control, $n=7$ cultures; TTX, $n=6$ cultures; TTX + A $\beta_{1-42}, n=7$ cultures; TTX + D-APV, $n=6$ cultures; TTX + KN93, $n=6$ cultures; APP ${ }^{+/+}$ Mann-Whitney test; $A P P^{-1-}$, Kruskal-Wallis test followed by Dunn's post hoc test). $\boldsymbol{H}$, Group data of AMPAR-mediated mEPSCs recorded from granule cells in synaptopodin-deficient $\left(S_{N P O^{-1-}}\right)$ tissue cultures. A $\beta_{1-42}(1.5 \mu \mathrm{m}, 2 \mathrm{~d})$ does not rescue TTX-induced homeostatic synaptic plasticity (untreated, $n=17$ cells from 6 cultures; TTX, $n=16$ cells from 5 cultures; TTX $+\mathrm{A} \beta_{1-42}, n=17$ cells from 5 cultures; Kruskal-Wallis test followed by Dunn's post hoc test). I, Model of APP/A $\beta$-mediated homeostatic synaptic scaling. APP/A $\beta$ is part of a $\mathrm{Ca}^{2+}$-dependent negative feedback mechanism that regulates synaptopodin cluster properties and synaptic accumulation of AMPAR in an NMDAR- and CaMKII-dependent manner. Plastic changes in synaptopodin cluster sizes and spine apparatuses were previously linked to synaptic plasticity (compare Vlachos et al., 2009; 2012; Lenz et al., 2021). Data are mean \pm SEM. NS, Not significant. ${ }^{*} p<0.05 .{ }^{* *} p<0.01$. ${ }^{* * *} p<0.001$.

processing via the "amyloidogenic pathway" could serve homeostatic synaptic plasticity. In the presence of $\mathrm{A} \beta$ (i.e., $\mathrm{A} \beta_{1-40}$ and $\mathrm{A} \beta_{1-42}$ ), the homeostatic synaptic response to TTX was fully restored in $A P P^{-/-}$preparations. Moreover, we report that pharmacological inhibition of $\beta$-secretases blocks TTX-induced homeostatic synaptic plasticity in WT cultures. Because pharmacological inhibition of $\gamma$-secretase had a similar effect, and $\mathrm{A} \beta$ rescued homeostatic synaptic plasticity in the presence of $\beta$ - or $\gamma$-secretase inhibitors, other APP cleavage products [e.g.,
APPs $\beta$ (or additional factors arising from $\beta$ - or $\gamma$-secretase processing)] are unlikely to account for our significant findings. In a previous study, however, pharmacological inhibition of $\gamma$-secretases did not block TTX-induced homeostatic synaptic plasticity (Pratt et al., 2011). These earlier experiments were conducted in primary hippocampal neurons rather than in organotypic tissue cultures, and L685458 (5 $\mu \mathrm{M})$ was used instead of Begacestat $(1 \mu \mathrm{M})$ in our study. These differences may explain the inconsistent results. Notably, we confirmed that pharma- 
cological inhibition of $\gamma$-secretase with Begacestat reduced endogenous $\mathrm{A} \beta$ levels in our experimental setting, and exogenous A $\beta_{1-42}$ rescued homeostatic synaptic plasticity in Begacestattreated tissue cultures.

To provide further evidence for the role of $\mathrm{A} \beta$ in neuronal physiology, we used antibodies against $\mathrm{A} \beta$ and scavenged endogenously produced $\mathrm{A} \beta$ from WT tissue cultures. This approach abolished homeostatic synaptic scaling in the WT cultures and prevented synaptic scaling in $A P P^{-1-}$ preparations cultured together with $A P P^{+/+}$tissue, whereas an antibody against APPs $\alpha$ did not affect TTX-induced synaptic scaling. Together, we propose a model in which APP processing via the non-amyloidogenic pathway and the amyloidogenic pathway influences the ability of a neuron to express distinct forms of synaptic plasticity: processing along the non-amyloidogenic pathway may promote Hebbian plasticity (e.g., LTP), whereas processing along the amyloidogenic pathway, or increased availability of $\mathrm{A} \beta$ (Gilbert et al., 2016), promotes homeostatic synaptic plasticity.

Interestingly, no major alterations in dendritic arborization, dendritic spines, PSDs, and spine apparatus organelles were observed in the dentate gyrus of $A P P^{-/-}$preparations (Fig. 4). Previous work demonstrated structural defects in $A P P^{-1-}$ CA1 pyramidal neurons (both in vitro and in vivo) (Wei et al., 2010; Tyan et al., 2012; Weyer et al., 2014). While additional work is required to determine the reasons for such region-specific difference (e.g., differential expression of APP) (Del Turco et al., 2016), we can state with confidence that major structural and functional alterations do not readily explain the major findings of the present study, also considering the experiments performed with WT tissue. Indeed, no differences in sEPSCs and sIPSCs, basic intrinsic properties, and synaptic NMDAR currents were observed in cultured dentate granule cells under baseline conditions between the genotypes.

What are the downstream pathways activated by $\mathrm{A} \beta$ in the context of homeostatic plasticity? Consistent with previous work on Hebbian plasticity (Zhao et al., 2004; Snyder et al., 2005; Gu et al., 2009; Zhang et al., 2009; Sinnen et al., 2016), we could link the homeostatic plasticity effects of $\mathrm{A} \beta$ to NMDARs and CaMKII. Considering the opposing roles of NMDARs and CaMKII in Hebbian and homeostatic synaptic plasticity, we speculated that $\mathrm{A} \beta$ signaling could be part of a $\mathrm{Ca}^{2+}$-dependent negative feedback mechanism that mediates homeostasis. Indeed, pharmacological inhibition of NMDARs and CaMKII rescued homeostatic synaptic plasticity in $A P P^{-1-}$ preparations, suggesting that $\mathrm{A} \beta$ acts on intracellular $\mathrm{Ca}^{2+}$ sensors or effectors, which responded to the TTX-induced reduction in intracellular $\mathrm{Ca}^{2+}$ in our experiments. Consistent with this suggestion, the previously reported $\mathrm{Ca}^{2+}$-dependent compensatory adjustment of synaptopodin was not observed in $A P P^{-1-}$ preparations (compare Vlachos et al., 2013), and interventions that rescued TTX-induced synaptic scaling in $A P P^{-1-}$ dentate granule cells also triggered compensatory changes in synaptopodin. Moreover, A $\beta$ was not able to rescue homeostatic synaptic plasticity in $S Y N P O^{-1-}$ preparations, demonstrating that synaptopodin is an essential downstream target through which APP/A $\beta$ asserts its effects on homeostatic synaptic plasticity.

In previous work, we have shown that the plasticity-related protein synaptopodin controls the ability of neurons to express both Hebbian and homeostatic synaptic plasticity (Deller et al., 2003; Jedlicka et al., 2009; Vlachos et al., 2009, 2013). Animals lacking this protein do not form spine apparatus organelles and exhibit deficits in Hebbian and homeostatic synaptic plasticity
(Deller et al., 2003; Jedlicka et al., 2009; Vlachos et al., 2013) because the $\mathrm{Ca}^{2+}$-dependent accumulation of AMPARs at excitatory postsynapses is impaired (e.g., Vlachos et al., 2009, 2013; Maggio and Vlachos, 2018). The results of the present study call for a systematic assessment of the activity-dependent molecular pathways through which APP processing via the "amyloidogenic/homeostatic" and "non-amyloidogenic/Hebbian plasticity promoting" pathways affects synaptopodin-mediated synaptic plasticity. It may be important to mention in this context that changes in synaptopodin expression have been reported in brain tissue from AD subjects (Reddy et al., 2005), and synaptopodin has been recently linked to autophagy of phospho-MAPT/Tau (Ji et al., 2019). Moreover, a reduction in synaptopodin expression seems to ameliorate symptoms in a transgenic mouse model of AD (Aloni et al., 2019).

A role of homeostatic synaptic plasticity in $\mathrm{AD}$ has been recently discussed (Jang and Chung, 2016; Styr and Slutsky, 2018). In the context of our data, which suggest a physiological role of $\mathrm{A} \beta$, it can be speculated that the previously reported "synaptotoxic" effects of A $\beta$ (e.g., Shankar et al., 2008; Mucke and Selkoe, 2012; Westmark, 2013; Wang et al., 2017; Zott et al., 2019) are the result of a pathologic overactivation of molecular machinery promoting synaptic homeostasis under physiological conditions. Consistent with this pathophysiological concept, $\mathrm{A} \beta$-mediated "alterations" in LTP in AD models might reflect, at least in part, enhanced homeostatic synaptic plasticity, which rapidly returns potentiated synapses to baseline after LTP induction (Galanis and Vlachos, 2020). Clearly, the biological consequences of the "amyloidogenic/ homeostatic" and the "non-amyloidogenic/Hebbian plasticity promoting" pathways warrant further investigation in the AD context, particularly because the amyloidogenic pathway is an important target for therapeutic intervention in AD (Yan and Vassar, 2014; Coimbra et al., 2018; Egan et al., 2019). Hence, some of the side effects observed in patients treated with $\beta$-secretase inhibitors (Coimbra et al., 2018; Egan et al., 2019) may have been caused by interference with the ability of healthy neurons to express homeostatic synaptic plasticity.

\section{References}

Abramov E, Dolev I, Fogel H, Ciccotosto GD, Ruff E, Slutsky I (2009) Amyloid-beta as a positive endogenous regulator of release probability at hippocampal synapses. Nat Neurosci 12:1567-1576.

Aimone JB, Deng W, Gage FH (2011) Resolving new memories: a critical look at the dentate gyrus, adult neurogenesis, and pattern separation. Neuron 70:589-596.

Aloni E, Oni-Biton E, Tsoory M, Moallem DH, Segal M (2019) Synaptopodin deficiency ameliorates symptoms in the $3 \times \mathrm{xTg}$ mouse model of Alzheimer's disease. J Neurosci 39:3983-3992.

Andre EA, Forcelli PA, Pak DT (2018) What goes up must come down: homeostatic synaptic plasticity strategies in neurological disease. Future Neurol 13:13-21.

Barao S, Moechars D, Lichtenthaler SF, De Strooper B (2016) BACE1 physiological functions may limit its use as therapeutic target for Alzheimer's disease. Trends Neurosci 39:158-169.

Barnes SJ, Franzoni E, Jacobsen RI, Erdelyi F, Szabo G, Clopath C, Keller GB, Keck T (2017) Deprivation-induced homeostatic spine scaling in vivo is localized to dendritic branches that have undergone recent spine loss. Neuron 96:871-882.e5.

Bohm C, Chen F, Sevalle J, Qamar S, Dodd R, Li Y, Schmitt-Ulms G, Fraser PE, St George-Hyslop PH (2015) Current and future implications of basic and translational research on amyloid-beta peptide production and removal pathways. Mol Cell Neurosci 66:3-11.

Chang EH, Savage MJ, Flood DG, Thomas JM, Levy RB, Mahadomrongkul V, Shirao T, Aoki C, Huerta PT (2006) AMPAR downscaling at the onset 
of Alzheimer's disease pathology in double knockin mice. Proc Natl Acad Sci USA 103:3410-3415.

Chen QS, Wei WZ, Shimahara T, Xie CW (2002) Alzheimer amyloid betapeptide inhibits the late phase of long-term potentiation through calcineurin-dependent mechanisms in the hippocampal dentate gyrus. Neurobiol Learn Mem 77:354-371.

Chow VW, Mattson MP, Wong PC, Gleichmann M (2010) An overview of APP processing enzymes and products. Neuromolecular Med 12:1-12.

Cingolani LA, Thalhammer A, Lily M, Catalano M, Ramos T, Colicos MA, Goda Y (2008) Activity-dependent regulation of synaptic AMPAR composition and abundance by $\beta 3$ integrins. Neuron 58:749-762.

Cirrito JR, May PC, O’Dell MA, Taylor JW, Parsadanian M, Cramer JW, Audia JE, Nissen JS, Bales KR, Paul SM, DeMattos RB, Holtzman DM (2003) In vivo assessment of brain interstitial fluid with microdialysis reveals plaque-associated changes in amyloid-beta metabolism and halflife. J Neurosci 23:8844-8853.

Coimbra JR, Marques DF, Baptista SJ, Pereira CM, Moreira PI, Dinis TC, Santos AE, Salvador JA (2018) Highlights in BACE1 inhibitors for Alzheimer's disease treatment. Front Chem 6:178.

Dawson GR, Seabrook GR, Zheng H, Smith DW, Graham S, O'Dowd G, Bowery BJ, Boyce S, Trumbauer ME, Chen HY, Van der Ploeg LH, Sirinathsinghji DJ (1999) Age-related cognitive deficits, impaired longterm potentiation and reduction in synaptic marker density in mice lacking the beta-amyloid precursor protein. Neuroscience 90:1-13.

Deller T, Korte M, Chabanis S, Drakew A, Schwegler H, Stefani GG, Zuniga A, Schwarz K, Bonhoeffer T, Zeller R, Frotscher M, Mundel P (2003) Synaptopodin-deficient mice lack a spine apparatus and show deficits in synaptic plasticity. Proc Natl Acad Sci USA 100:10494-10499.

Del Turco D, Paul MH, Schlaudraff J, Hick M, Endres K, Müller UC, Deller $\mathrm{T}$ (2016) Region-specific differences in amyloid precursor protein expression in the mouse hippocampus. Front Mol Neurosci 9:134

Echegoyen J, Neu A, Graber KD, Soltesz I (2007) Homeostatic plasticity studied using in vivo hippocampal activity-blockade: synaptic scaling, intrinsic plasticity and age-dependence. PLoS One 2:e700.

Egan MF, Kost J, Voss T, Mukai Y, Aisen PS, Cummings JL, Tariot PN, Vellas B, van Dyck CH, Boada M, Zhang Y, Li W, Furtek C, Mahoney E, Harper Mozley L, Mo Y, Sur C, Michelson D (2019) Randomized trial of verubecestat for prodromal Alzheimer's disease. N Engl J Med 380:14081420.

Fol R, Braudeau J, Ludewig S, Abel T, Weyer SW, Roederer JP, Brod F, Audrain M, Bemelmans AP, Buchholz CJ, Korte M, Cartier N, Müller UC (2016) Viral gene transfer of APPs $\alpha$ rescues synaptic failure in an Alzheimer's disease mouse model. Acta Neuropathol 131:247-266.

Friedman HR, Goldman-Rakic PS (1988) Activation of the hippocampus and dentate gyrus by working-memory: a 2-deoxyglucose study of behaving rhesus monkeys. J Neurosci 8:4693-4706.

Galanis C, Vlachos A (2020) Hebbian and homeostatic synaptic plasticity: do alterations of one reflect enhancement of the other? Front Cell Neurosci 14:50.

Gilbert J, Shu S, Yang X, Lu Y, Zhu LQ, Man HY (2016) beta-Amyloid triggers aberrant over-scaling of homeostatic synaptic plasticity. Acta Neuropathol Commun 4:131.

Goddard CA, Butts DA, Shatz CJ (2007) Regulation of CNS synapses by neuronal MHC class I. Proc Natl Acad Sci USA 104:6828-6833.

Gray E (1959) Electron microscopy of synaptic contacts on dendrite spines of the cerebral cortex. Nature 183:1592-1593.

Gu Z, Liu W, Yan Z (2009) $\beta$-Amyloid impairs AMPAR trafficking and function by reducing $\mathrm{Ca}^{2+} /$ calmodulin-dependent protein kinase II synaptic distribution. J Biol Chem 284:10639-10649.

Hashimoto M, Bogdanovic N, Volkmann I, Aoki M, Winblad B, Tjernberg LO (2010) Analysis of microdissected human neurons by a sensitive ELISA reveals a correlation between elevated intracellular concentrations of Abeta42 and Alzheimer's disease neuropathology. Acta Neuropathol 119:543-554.

Herms J, Anliker B, Heber S, Ring S, Fuhrmann M, Kretzschmar H, Sisodia S, Muller U (2004) Cortical dysplasia resembling human type 2 lissencephaly in mice lacking all three APP family members. EMBO J 23:41064115.

Hick M, Herrmann U, Weyer SW, Mallm JP, Tschäpe JA, Borgers M, Mercken M, Roth FC, Draguhn A, Slomianka L, Wolfer DP, Korte M, Müller UC (2015) Acute function of secreted amyloid precursor protein fragment APPsalpha in synaptic plasticity. Acta Neuropathol 129:21-37.
Hoe HS, Lee HK, Pak DT (2012) The upside of APP at synapses. CNS Neurosci Ther 18:47-56.

Jang SS, Chung HJ (2016) Emerging link between Alzheimer's disease and homeostatic synaptic plasticity. Neural Plast 2016:7969272.

Jedlicka P, Schwarzacher SW, Winkels R, Kienzler F, Frotscher M, Bramham CR, Schultz C, Bas Orth C, Deller T (2009) Impairment of in vivo thetaburst long-term potentiation and network excitability in the dentate gyrus of synaptopodin-deficient mice lacking the spine apparatus and the cisternal organelle. Hippocampus 19:130-140.

Ji C, Tang M, Zeidler C, Hohfeld J, Johnson GV (2019) BAG3 and SYNPO (synaptopodin) facilitate phospho-MAPT/Tau degradation via autophagy in neuronal processes. Autophagy 15:1199-1213.

Kamenetz F, Tomita T, Hsieh H, Seabrook G, Borchelt D, Iwatsubo T, Sisodia S, Malinow R (2003) APP processing and synaptic function. Neuron 37:925-937.

Kim J, Tsien RW (2008) Synapse-specific adaptations to inactivity in hippocampal circuits achieve homeostatic gain control while dampening network reverberation. Neuron 58:925-937.

Konietzny A, Gonzalez-Gallego J, Bar J, Perez-Alvarez A, Drakew A, Demmers JA, Dekkers DH, Hammer JA 3rd, Frotscher M, Oertner TG, Wagner W, Kneussel M, Mikhaylova M (2019) Myosin V regulates synaptopodin clustering and localization in the dendrites of hippocampal neurons. J Cell Sci 132:jcs230177.

Lazarevic V, Fieńko S, Andres-Alonso M, Anni D, Ivanova D, MontenegroVenegas C, Gundelfinger ED, Cousin MA, Fejtova A (2017) Physiological concentrations of amyloid beta regulate recycling of synaptic vesicles via alpha7 acetylcholine receptor and CDK5/calcineurin signaling. Front Mol Neurosci 10:221.

Lenz M, Galanis C, Kleidonas D, Fellenz M, Deller T, Vlachos A (2019) Denervated mouse dentate granule cells adjust their excitatory but not inhibitory synapses following in vitro entorhinal cortex lesion. Exp Neurol 312:1-9.

Lenz M, Kruse P, Eichler A, Straehle J, Beck J, Deller T, Vlachos A (2021) All-trans retinoic acid induces synaptic plasticity in human cortical neurons. Elife 10:e63026.

Li ZW, Stark G, Gotz J, Rulicke T, Gschwind M, Huber G, Muller U, Weissmann C (1996) Generation of mice with a 200-kb amyloid precursor protein gene deletion by Cre recombinase-mediated site-specific recombination in embryonic stem cells. Proc Natl Acad Sci USA 93:6158-6162.

Lichtenthaler SF, Haass C, Steiner H (2011) Regulated intramembrane proteolysis: lessons from amyloid precursor protein processing. J Neurochem 117:779-796.

Lisman J (2017) Glutamatergic synapses are structurally and biochemically complex because of multiple plasticity processes: long-term potentiation, long-term depression, short-term potentiation and scaling. Philos Trans R Soc Lond B Biol Sci 372:20160260.

Ludewig S, Korte M (2016) Novel insights into the physiological function of the APP (gene) family and its proteolytic fragments in synaptic plasticity. Front Mol Neurosci 9:161.

Magara F, Muller U, Li ZW, Lipp HP, Weissmann C, Stagljar M, Wolfer DP (1999) Genetic background changes the pattern of forebrain commissure defects in transgenic mice underexpressing the beta-amyloid-precursor protein. Proc Natl Acad Sci USA 96:4656-4661.

Maggio N, Vlachos A (2018) Tumor necrosis factor (TNF) modulates synaptic plasticity in a concentration-dependent manner through intracellular calcium stores. J Mol Med 96:1039-1047.

Martone RL, Zhou H, Atchison K, Comery T, Xu JZ, Huang X, Gong X, Jin M, Kreft A, Harrison B, Mayer SC, Aschmies S, Gonzales C, Zaleska MM, Riddell DR, Wagner E, Lu P, Sun SC, Sonnenberg-Reines J, Oganesian A, et al. (2009) Begacestat (GSI-953): a novel, selective thiophene sulfonamide inhibitor of amyloid precursor protein gamma-secretase for the treatment of Alzheimer's disease. J Pharmacol Exp Ther 331:598-608.

Mockett BG, Richter M, Abraham WC, Muller UC (2017) Therapeutic potential of secreted amyloid precursor protein APPsalpha. Front Mol Neurosci 10:30.

Mucke L, Selkoe DJ (2012) Neurotoxicity of amyloid beta-protein: synaptic and network dysfunction. Cold Spring Harb Perspect Med 2 2:a006338.

Muller U, Cristina N, Li ZW, Wolfer DP, Lipp HP, Rulicke T, Brandner S, Aguzzi A, Weissmann C (1994) Behavioral and anatomical deficits in 
mice homozygous for a modified beta-amyloid precursor protein gene. Cell 79:755-765.

Müller UC, Deller T, Korte M (2017) Not just amyloid: physiological functions of the amyloid precursor protein family. Nat Rev Neurosci 18:281298.

Novotny R, Langer F, Mahler J, Skodras A, Vlachos A, Wegenast-Braun BM, Kaeser SA, Neher JJ, Eisele YS, Pietrowski MJ, Nilsson KP, Deller T, Staufenbiel M, Heimrich B, Jucker M (2016) Conversion of synthetic Abeta to in vivo active seeds and amyloid plaque formation in a hippocampal slice culture model. J Neurosci 36:5084-5093.

Opazo P, Viana da Silva S, Carta M, Breillat C, Coultrap SJ, Grillo-Bosch D, Sainlos M, Coussen F, Bayer KU, Mulle C, Choquet D (2018) CaMKII metaplasticity drives Abeta oligomer-mediated synaptotoxicity. Cell Rep 23:3137-3145.

Pratt KG, Zimmerman EC, Cook DG, Sullivan JM (2011) Presenilin 1 regulates homeostatic synaptic scaling through Akt signaling. Nat Neurosci 14:1112-1114.

Puzzo D, Privitera L, Leznik E, Fà M, Staniszewski A, Palmeri A, Arancio O (2008) Picomolar amyloid-beta positively modulates synaptic plasticity and memory in hippocampus. J Neurosci 28:14537-14545.

Puzzo D, Privitera L, Fa M, Staniszewski A, Hashimoto G, Aziz F, Sakurai M, Ribe EM, Troy CM, Mercken M, Jung SS, Palmeri A, Arancio O (2011) Endogenous amyloid-beta is necessary for hippocampal synaptic plasticity and memory. Ann Neurol 69:819-830.

Radic T, Jungenitz T, Singer M, Beining M, Cuntz H, Vlachos A, Deller T, Schwarzacher SW (2017) Time-lapse imaging reveals highly dynamic structural maturation of postnatally born dentate granule cells in organotypic entorhino-hippocampal slice cultures. Sci Rep 7:43724.

Reddy PH, Mani G, Park BS, Jacques J, Murdoch G, Whetsell W Jr, Kaye J, Manczak M (2005) Differential loss of synaptic proteins in Alzheimer's disease: implications for synaptic dysfunction. J Alzheimers Dis 7:103117; discussion 173-180.

Rice HC, de Malmazet D, Schreurs A, Frere S, Van Molle I, Volkov AN, Creemers E, Vertkin I, Nys J, Ranaivoson FM, Comoletti D, Savas JN, Remaut H, Balschun D, Wierda KD, Slutsky I, Farrow K, De Strooper B, de Wit J (2019) Secreted amyloid- $\beta$ precursor protein functions as a GABABR1a ligand to modulate synaptic transmission. Science 363: eaao4827.

Richter MC, Ludewig S, Winschel A, Abel T, Bold C, Salzburger LR, Klein S, Han K, Weyer SW, Fritz AK, Laube B, Wolfer DP, Buchholz CJ, Korte M, Müller UC (2018) Distinct in vivo roles of secreted APP ectodomain variants APPsalpha and APPsbeta in regulation of spine density, synaptic plasticity, and cognition. EMBO J 37:e98335.

Ring S, Weyer SW, Kilian SB, Waldron E, Pietrzik CU, Filippov MA, Herms J, Buchholz C, Eckman CB, Korte M, Wolfer DP, Müller UC (2007) The secreted beta-amyloid precursor protein ectodomain APPs alpha is sufficient to rescue the anatomical, behavioral, and electrophysiological abnormalities of APP-deficient mice. J Neurosci 27:7817-7826.

Seabrook GR, Smith DW, Bowery BJ, Easter A, Reynolds T, Fitzjohn SM, Morton RA, Zheng H, Dawson GR, Sirinathsinghji DJ, Davies CH, Collingridge GL, Hill RG (1999) Mechanisms contributing to the deficits in hippocampal synaptic plasticity in mice lacking amyloid precursor protein. Neuropharmacology 38:349-359.

Seubert P, Vigo-Pelfrey C, Esch F, Lee M, Dovey H, Davis D, Sinha S, Schiossmacher M, Whaley J, Swindlehurst C, McCormack R, Wolfert R, Selkoe D, Lieberburg I, Schenk D (1992) Isolation and quantification of soluble Alzheimer's beta-peptide from biological fluids. Nature 359:325327.

Shankar GM, Li S, Mehta TH, Garcia-Munoz A, Shepardson NE, Smith I, Brett FM, Farrell MA, Rowan MJ, Lemere CA, Regan CM, Walsh DM, Sabatini BL, Selkoe DJ (2008) Amyloid-beta protein dimers isolated directly from Alzheimer's brains impair synaptic plasticity and memory. Nat Med 14:837-842.

Shoji M, Golde T, Ghiso J, Cheung T, Estus S, Shaffer L, Cai X, McKay D, Tintner R, Frangione B (1992) Production of the Alzheimer amyloid beta protein by normal proteolytic processing. Science 258:126-129.

Sinnen BL, Bowen AB, Gibson ES, Kennedy MJ (2016) Local and use-dependent effects of beta-amyloid oligomers on NMDA receptor function revealed by optical quantal analysis. J Neurosci 36:11532-11543.

Smith-Dijak AI, Nassrallah WB, Zhang LY, Geva M, Hayden MR, Raymond LA (2019) Impairment and restoration of homeostatic plasticity in cultured cortical neurons from a mouse model of Huntington disease. Front Cell Neurosci 13:209.

Snyder EM, Nong Y, Almeida CG, Paul S, Moran T, Choi EY, Nairn AC, Salter MW, Lombroso PJ, Gouras GK, Greengard P (2005) Regulation of NMDAR trafficking by amyloid-beta. Nat Neurosci 8:1051-1058.

Spacek J (1985) Three-dimensional analysis of dendritic spines. Anat Embryol (Berl) 171:245-252.

Spacek J, Harris KM (1997) Three-dimensional organization of smooth endoplasmic reticulum in hippocampal CA1 dendrites and dendritic spines of the immature and mature rat. J Neurosci 17:190-203.

Stachel SJ, Coburn CA, Steele TG, Jones KG, Loutzenhiser EF, Gregro AR, Rajapakse HA, Lai MT, Crouthamel MC, Xu M, Tugusheva K, Lineberger JE, Pietrak BL, Espeseth AS, Shi XP, Chen-Dodson E, Holloway MK, Munshi S, Simon AJ, Kuo L, et al. (2004) Structure-based design of potent and selective cell-permeable inhibitors of human betasecretase (BACE-1). J Med Chem 47:6447-6450.

Stellwagen D, Malenka RC (2006) Synaptic scaling-mediated by glial TNFalpha. Nature 440:1054-1059.

Strehl A, Galanis C, Radic T, Schwarzacher SW, Deller T, Vlachos A (2018) Dopamine modulates homeostatic excitatory synaptic plasticity of immature dentate granule cells in entorhino-hippocampal slice cultures. Front Mol Neurosci 11:303.

Styr B, Slutsky I (2018) Imbalance between firing homeostasis and synaptic plasticity drives early-phase Alzheimer's disease. Nat Neurosci 21:463473.

Sun Q, Turrigiano GG (2011) PSD-95 and PSD-93 play critical but distinct roles in synaptic scaling up and down. J Neurosci 31:6800-6808.

Sutton MA, Ito HT, Cressy P, Kempf C, Woo JC, Schuman EM (2006) Miniature neurotransmission stabilizes synaptic function via tonic suppression of local dendritic protein synthesis. Cell 125:785-799.

Tan VT, Mockett BG, Ohline SM, Parfitt KD, Wicky HE, Peppercorn K, Schoderboeck L, Yahaya MFB, Tate WP, Hughes SM, Abraham WC (2018) Lentivirus-mediated expression of human secreted amyloid precursor protein-alpha prevents development of memory and plasticity deficits in a mouse model of Alzheimer's disease. Mol Brain 11:7.

Taylor CJ, Ireland DR, Ballagh I, Bourne K, Marechal NM, Turner PR, Bilkey DK, Tate WP, Abraham WC (2008) Endogenous secreted amyloid precursor protein-alpha regulates hippocampal NMDAR function, longterm potentiation and spatial memory. Neurobiol Dis 31:250-260.

Townsend M, Mehta T, Selkoe DJ (2007) Soluble Abeta inhibits specific signal transduction cascades common to the insulin receptor pathway. J Biol Chem 282:33305-33312.

Turrigiano GG (1999) Homeostatic plasticity in neuronal networks: the more things change, the more they stay the same. Trends Neurosci 22:221-227.

Turrigiano GG (2008) The self-tuning neuron: synaptic scaling of excitatory synapses. Cell 135:422-435.

Turrigiano GG, Leslie KR, Desai NS, Rutherford LC, Nelson SB (1998) Activity-dependent scaling of quantal amplitude in neocortical neurons. Nature 391:892-896.

Tyan SH, Shih AY, Walsh JJ, Maruyama H, Sarsoza F, Ku L, Eggert S, Hof PR, Koo EH, Dickstein DL (2012) Amyloid precursor protein (APP) regulates synaptic structure and function. Mol Cell Neurosci 51:43-52.

Vlachos A, Becker D, Jedlicka P, Winkels R, Roeper J, Deller T (2012) Entorhinal denervation induces homeostatic synaptic scaling of excitatory postsynapses of dentate granule cells in mouse organotypic slice cultures. PLoS One 7:e32883.

Vlachos A, Ikenberg B, Lenz M, Becker D, Reifenberg K, Bas-Orth C, Deller $\mathrm{T}$ (2013) Synaptopodin regulates denervation-induced homeostatic synaptic plasticity. Proc Natl Acad Sci USA 110:8242-8247.

Vlachos A, Korkotian E, Schonfeld E, Copanaki E, Deller T, Segal M (2009) Synaptopodin regulates plasticity of dendritic spines in hippocampal neurons. J Neurosci 29:1017-1033.

von Koch CS, Zheng H, Chen H, Trumbauer M, Thinakaran G, van der Ploeg LH, Price DL, Sisodia SS (1997) Generation of APLP2 KO mice and early postnatal lethality in APLP2/APP double KO mice. Neurobiol Aging 18:661-669.

Walters BJ, Josselyn SA (2019) Retinoic acid receptor plays both sides of homeostatic plasticity. Proc Natl Acad Sci USA 116:6528-6530.

Wang Z, Jackson RJ, Hong W, Taylor WM, Corbett GT, Moreno A, Liu W, Li S, Frosch MP, Slutsky I, Young-Pearse TL, Spires-Jones TL, Walsh DM (2017) Human brain-derived A $\beta$ oligomers bind to synapses and 
disrupt synaptic activity in a manner that requires APP. J Neurosci 37:11947-11966.

Wei W, Nguyen LN, Kessels HW, Hagiwara H, Sisodia S, Malinow R (2010) Amyloid beta from axons and dendrites reduces local spine number and plasticity. Nat Neurosci 13:190-196.

Westmark CJ (2013) What's hAPPening at synapses? The role of amyloid beta-protein precursor and beta-amyloid in neurological disorders. Mol Psychiatry 18:425-434.

Weyer SW, Zagrebelsky M, Herrmann U, Hick M, Ganss L, Gobbert J, Gruber M, Altmann C, Korte M, Deller T, Muller UC (2014) Comparative analysis of single and combined APP/APLP knockouts reveals reduced spine density in APP-KO mice that is prevented by APPsalpha expression. Acta Neuropathol Commun 2:36.

Yan R, Vassar R (2014) Targeting the beta secretase BACE1 for Alzheimer's disease therapy. Lancet Neurol 13:319-329.

Zhang J, Hou L, Gao X, Guo F, Jing W, Qi J, Qiao J (2009) Amyloid $\beta$-protein differentially affects NMDAR- and GABAA receptor-mediated currents in rat hippocampal CA1 neurons. Prog Natural Sci 19:963972.

Zhao D, Watson JB, Xie CW (2004) Amyloid beta prevents activation of calcium/calmodulin-dependent protein kinase II and AMPAR phosphorylation during hippocampal long-term potentiation. J Neurophysiol 92:2853-2858.

Zheng H, Koo EH (2011) Biology and pathophysiology of the amyloid precursor protein. Mol Neurodegeneration 6:27.

Zheng $H$, Jiang $M$, Trumbauer ME, Sirinathsinghji DJ, Hopkins R, Smith DW, Heavens RP, Dawson GR, Boyce S, Conner MW, Stevens KA, Slunt HH, Sisodia SS, Chen HY, Van der Ploeg LH (1995) beta-Amyloid precursor protein-deficient mice show reactive gliosis and decreased locomotor activity. Cell $81: 525-531$

Zott B, Simon MM, Hong W, Unger F, Chen-Engerer HJ, Frosch MP, Sakmann B, Walsh DM, Konnerth A (2019) A vicious cycle of beta amyloid-dependent neuronal hyperactivation. Science 365:559565 